Article

\title{
Impact of Plant Growth Promoting Rhizobacteria in the Orchestration of Lycopersicon esculentum Mill. Resistance to Plant Parasitic Nematodes: A Metabolomic Approach to Evaluate Defense Responses Under Field Conditions
}

\author{
Kanika Khanna ${ }^{1}$, Anket Sharma ${ }^{1,2}{ }^{\circledR}$, Puja Ohri ${ }^{3, *}$, Renu Bhardwaj ${ }^{1, *}$, Elsayed F. Abd_Allah ${ }^{4}($, \\ Abeer Hashem ${ }^{5,6}$ and Parvaiz Ahmad 5,7,*(D) \\ 1 Department of Botanical and Environmental Sciences, Guru Nanak Dev University, Amritsar 143005, India; \\ kanika.27590@gmail.com (K.K.); anketsharma@gmail.com (A.S.) \\ 2 State Key Laboratory of Subtropical Silviculture, Zhejiang A\&F University, Hangzhou 311300, China \\ Department of Zoology, Guru Nanak Dev University, Amritsar 143005, India \\ 4 Department of Plant Production, Faculty of Food \& Agricultural Sciences, King Saud University, \\ Riyadh 11451, Saudi Arabia; eabdallah@ksu.edu.sa \\ 5 Botany and Microbiology Department, College of Science, King Saud University, P.O. Box. 2460, \\ Riyadh 11451, Saudi Arabia; habeer@ksu.edu.sa \\ 6 Mycology and Plant Disease Survey Department, Plant Pathology Research Institute, ARC, Giza 12511, Egypt \\ 7 Department of Botany, S.P. College, Srinagar, Jammu and Kashmir 190001, India \\ * Correspondence: ohri11puja@gmail.com (P.O.); renubhardwaj82@gmail.com (R.B.); \\ parvaizbot@yahoo.com (P.A.)
}

Received: 29 September 2019; Accepted: 25 October 2019; Published: 31 October 2019

check for updates

\begin{abstract}
The present study deals with biological control of Meloidogyne incognita in 45-days old Lycopersicon esculentum, inoculated with Pseudomonas aeruginosa(M1) and Burkholderia gladioli (M2). The improved plant growth and biomass of nematode infested Plant growth promoting rhizobacteria (PGPR) inoculated plants was observed. Remarkable reduction in the numbers of second stage juvenile (J2s), root galls was recorded after treatment of microbes relative to experimental controls. Moreover, the lowered activities of oxidative stress markers $\left(\mathrm{H}_{2} \mathrm{O}_{2}\right.$ (hydrogen peroxide), $\mathrm{O}_{2}{ }^{-}$(superoxide anion), malondialdehyde (MDA)) was estimated in plants after rhizobacterial supplementation. Higher activities of enzymatic (SOD (Superoxide dismutase), POD (Guaiacol peroxidase), CAT (Catalase), GPOX (Glutathione peroxidase), APOX (Ascorbate peroxidase), GST (Glutathione-S-transferase), GR (Glutathione reductase), DHAR (Dehydroascorbate reductase), PPO (Polyphenol oxidase)) and non-enzymatic (glutathione, ascorbic acid, tocopherol) antioxidants were further determined in nematode infected plants following the addition of bacterial strains. The upregulation of photosynthetic activities were depicted by evaluating plant pigments and gas exchange attributes. An increase in the levels of phenolic compounds (total phenols, flavonoids, anthocyanins), osmoprotectants (total osmolytes, carbohydrates, reducing sugars, trehalose, proline, glycine betaine, free amino acids) and organic acids (fumaric, succinic, citric, malic acid) were reflected in infected plants, showing further enhancement after application of biocontrol agents. The study revealed the understanding of plant metabolism, along with the initiative to commercially exploit the biocontrol agents as an alternative to chemical nematicides in infected fields for sustainable agriculture.
\end{abstract}

Keywords: root knot nematodes; biocontrol agents; Lycopersicon esculentum; photosynthetic parameters; oxidative damage; antioxidants; phenolics; osmoprotectants and organic acid profiling 


\section{Introduction}

Lycopersicon esculentum Mill. is one of the most important crops of the world that is mostly cultivated by the farmers after potato due of its broader adaptability, high yield and its suitability for number of uses in fresh and processed food markets [1]. It is considered to be a high nutrient value crop due to its abundant health benefits, as it is comprised of higher vitamin $C$, flavonoids, carotenoids ( $\beta$-carotenes), folate, water soluble antioxidants, and a range of phytochemicals that are effective against cancer and many other deadly diseases [2].

Due to sky-rocketed world population, it is very challenging to maintain the standard and productivity of food supplies for the entire population. It has been recently reported that, productivity of the tomato crop has dwindled worldwide, due to amyriad of diseases caused by pests and pathogens, specifically plant-parasitic nematodes (PPNs) [3]. The PPNs plummet nearly about 100 billion dollars of yearly agricultural losses, in spite of using all the commercially available methods for nematode management [4]. This has been mediated by fluctuation in the global temperatures caused by climatic factors, favouring PPNs population in soil either by affecting their life cycle or altering the host machinery and facilitating the infection process to take place [5].

The PPN, Meloidogyne incognita is a microscopic, soil inhabiting nematode that mainly feeds on living plant cells [6]. The J2 (second stage juvenile) is the infectious stage, that enters into the plant via roots and migrate across intercellular spaces towards vascular tissues [7]. After getting effectively established within the plant tissues, they migrate towards the nearby cells and initiate the formation of permanent feeding sites. The feeding cells or sites are composed of giant cells (multinucleate) that mature to form recognisable knots or galls onto root surfaces [8]. These are the regions within which PPNs proliferate and develop, thereby, launching an interactive association with the plants $[7,9]$. The PPN releases effector proteins from stylet to initiate the parasitic relationship with plants in for maintaining the feeding sites [10]. PPNs modifies the plant cell wall, host protein machinery and defense proteins, leading to protein denaturation and transcriptional changes in the different metabolic processes of plants [11]. The symptoms show the formation of root galls, hypertrophic or hyperplasic roots, disturbance in water and mineral transport, and inhibition in water-nutrient balance that leads to chlorosis and disrupted photosynthetic attributes of plants [12]. Moreover, they can also provoke morphological alterations of feeding cells, enlargement of nuclei, condensation of cytoplasmic bridges, disorientation of vacuoles and proliferation of other organelles such as plastids and mitochondria [13]. In addition, they enhance the susceptibility of infected plants towards other pathogens such as Fusarium, etc. [14].

At present, the management strategies employ the consumption of synthetically derived chemical nematicides to control the PPN proliferation in the fields or practising resistant plant varieties $[15,16]$. However, taking into consideration the harsh effects of nematicides on environment as well as flora and fauna, their use have been noticeably reduced [17]. Other strategies include the use of crop resistant varieties and crop rotation methods, which come with many limitations [3]. Therefore, the present scenario provides an impetus to look for an alternative and environmental friendly practice for controlling PPNs.

Plant growth promoting rhizobacteria (PGPR), a ubiquitous group of micro-organisms inhabiting rhizosphere have the potential to be greatly used as biocontrol agents $[18,19]$. They confer many vitalfunctions to the host plants such as releasing various phytohormones (Indole-3-acetic acid (IAA), ethylene, ABA, gibberellins, salicylic acid, cytokinins), enzymes (ACC (1-aminocyclopropane-1carboxylate)-deaminase, chitinases, glucanases etc.), phosphate solubilization, siderophore production, nitrogen fixation and protection towards different pathogenic organisms including PPNs [20,21]. The PGPR mediated plant resistance towards PPNs is provided by production of various antagonistic compounds, lytic enzymes, toxins and antibiotics that inhibit the nematode proliferation or directly killing them [22]. Moreover, PGPR also colonises the plant roots in the rhizosphere, produces various metabolites and their by-products that either affect the motility of PPN, or their emergence and penetration within the plant roots [23]. In addition, they also protect plants through ISR (induced 
systemic resistance) and synthesising quorum sensing molecules (for e.g., acylhomoserine lactone) toregulate the activities of nematodes in the rhizosphere [24,25]. Several PGPR genera that have been used as biocontrol agents include Azospirillum, Azotobacter, Pseudomonas, Gluconacetobacter, Azoarcus, Bradyrhizobium, Burkholderia, Bacillus, Alcaligenes, Paenibacillus, Serratia etc. [26-29]. Furthermore, PGPR also comes up with the interior functions of the plants such as maintaining the ROS levels generated inside plant through effective scavenging mechanisms $[16,30]$. They also trigger the antioxidant levels in plants (enzymatic and non-enzymatic) during nematode infection, a prerequisite for triggering defense responses within them [31]. The PGPR have also been significantly known to modulate the levels of plant metabolites by up-regulating the enzymatic activities of secondary metabolites such as phenols, sugars, amino acids and organic acids $[23,26]$. In addition, PGPR were found to induce ISR in tomato plants infested with nematodes through modulating the biochemical profiles of plants [26]. The various biochemical analysis revealed that host plant develops resistance against PPN via activating or de-activating of certain enzymes involved in physiological and biochemical processes of plants [23].Especially, the strains from genera Pseudomonas and Burkholderia have been used as the biological control agents for PPNs in L. esculentum, as observed in our previous studies conducted on 10-days old seedlings [32]. It was reported that PGPR strains led to improved tomato resistance from PPN infection through activation of different antioxidant mechanisms with plants that directly scavenged the free radicals generated in response to infection [32].

The present research was carried out as extension to our previous studies to explore the role of Pseudomonas aeruginosa (MTCC7195; M1) and Burkholderia gladioli (MTCC10242; M2) on 45-days old nematode infested L. esculentum plants raised under field conditions. The morphological parameters, plant pigments, gas exchange parameters, oxidative damage, enzymatic and non-enzymatic antioxidants, phenolic compounds, osmoprotectants and organic acids were assessed in the present study.

\section{Materials and Methods}

\subsection{Biocontrol Agents}

Two plant growth promoting rhizobacterial strains, Pseudomonas aeruginosa; MTCC7195 (M1) and Burkholderia gladioli; MTCC10242 (M2) were used as biocontrol agents in the present study. Strainswere purchased from IMTECH (Mohali, Punjab, India) in the lyophilized form, sealed in the culture tubes. They were revived in laminar air flow under aseptic conditions using $50 \mathrm{~mL}$ Nutrient broth media and placed in incubator with temperature conditions of $28^{\circ} \mathrm{C}$ for $24-48 \mathrm{~h}$. Later, they were sub-cultured time to time for further use. After that, $1 \mathrm{~mL}$ of broth culture was taken and inoculated into autoclaved $50 \mathrm{~mL}$ nutrient broth media and placed in incubator at specific conditions for bacterial proliferation. This was further spun in the centrifuge at $8,000 \mathrm{rpm}$ for $10-15 \mathrm{~min}$ at $4{ }^{\circ} \mathrm{C}$, until the pellet was formed. The supernatant was removed and pellet was washed thoroughly using double distilled water. After washing the pellet, it was suspended in double distilled water and $10^{9}$ cells $/ \mathrm{mL}$ population was maintained.

\subsection{Root-knot Nematode (Meloidogyne incognita) Culture}

The M. incognita culture was raised and maintained in green house by collection of samples from infected sites. M. incognita was recognized, screened and isolated from the sites to use it further for experimental purpose. They were identified by assessing perineal patterns of females that are formed by expansion or alteration of juvenile bodies, followed by retained tail tips, lateral patterns or presence of phasmids [33]. The roots were washed and cleaned properly $(0.9 \%$ saline solution) to remove the soil particles. The egg masses were carefully taken off from infected roots and suspended into $45 \%$ lactic acid solution. They were allowed to hatch in distilled water into second stage juveniles which were further used to inoculate the tomato and brinjal seedlings raised for maintaining the pure cultures. Second stage juveniles obtained from cultures were then used for experimentation. 


\subsection{Raising of Plants}

Authoritative seeds of L. esculentum Mill. (var. Pusa Ruby) were purchased from market, sterilized by $0.01 \%$ mercuric chloride and rinsed for 4,5 times with double distilled water. Soil was prepared by mixing garden soil, sand and organic manure in 3:1:1 ratio followed by autoclaving. Pots were washed and cleaned thoroughly and filled with $300 \mathrm{~g}$ soil mixture to which the seeds were sown. After the appearance of true leaves, inoculation of $M$. incognita was given near roots (300 J2s). Later, the soil was given rhizobacterial treatment after the onset of germination and inoculation of $M$. incognita. The pots were marked and kept under field conditions and irrigated properly. The harvesting was done carefully after 45-days of inoculation/germination by washing the roots with distilled water to get rid of soil particles. The plants were stored to carry out morphological, physiological and biochemical investigations.

\subsection{Growth Attributes}

The growth attributes of 45-days old L. esculentum plants were measured through assessing root length and shoot length. Further, plant biomass was also determined in terms of fresh weight and dry weight of samples.

\subsection{Photosynthetic Pigments}

\subsubsection{Total Chlorophyll and Carotenoid Content}

The estimation of total chlorophyll and carotenoid content was done by Arnon [34] and Maclachlan and Zalik [35] method. For this, $1 \mathrm{~g}$ sample was grounded in $80 \%$ acetone, followed by centrifugation in cooling centrifuge with $4{ }^{\circ} \mathrm{C}$ at $10,000 \mathrm{rpm}$ for $15 \mathrm{~min}$. After that, absorbance of supernatant was read at 645 and $663 \mathrm{~nm}$ respectively for total chl and 480 and $510 \mathrm{~nm}$ for carotenoid content.

\subsubsection{Total Xanthophyll Content}

Estimation of total xanthophyll content was done by Lawrence [36] protocol. For this purpose, $50 \mathrm{mg}$ plant sample completely dried and crushed was taken in the flask. The extractant $(30 \mathrm{~mL})$ was prepared by combining hexane $(10 \mathrm{~mL})$ : absolute alcohol $(6 \mathrm{~mL})$ : toluene $(7 \mathrm{~mL})$ : acetone $(7 \mathrm{~mL})$ and transferred and meticulously mixed for $15 \mathrm{~min}$. To this, $2 \mathrm{~mL} 40 \%$ Met. $\mathrm{KOH}$ was mixed and heated to $58^{\circ} \mathrm{C}$ in water bath. Sample incubation was done under dark conditions for an hour after which $30 \mathrm{~mL}$ of hexane in addition to $10 \% \mathrm{Na}_{2} \mathrm{SO}_{4}$ was combined in flask to make it to $100 \mathrm{~mL}$ volume. Again, incubations for an hour were done under dark conditions after vigorously mixing the contents. Later, the upper layer was removed to other flask and hexane was added to make final contents of $50 \mathrm{~mL}$ after which the optical density at $474 \mathrm{~nm}$ was read.

\subsubsection{Gaseous Exchange Parameters}

The measurement of gas exchange attributes were done in 45-days old plants. Estimation of Net photosynthetic rate (Pn), Transpiration rate (E), Stomatal conductance (Gs) and intercellular $\mathrm{CO}_{2}$ rate (Ci) was done by Portable Photosynthesis Measuring System Unit (Li COR-6400, LiCOR Instruments, Lincoln, NE, USA) during sunny day. Maintenance of relative humidity $(80-90 \%)$; temperature $\left(25^{\circ} \mathrm{C}\right)$; photon flux density $\left(1000 \mu \mathrm{mol} \mathrm{m}^{-2} \mathrm{~g}^{-1}\right)$ and $\mathrm{CO}_{2}$ rate $\left(400 \mu \mathrm{mol} \mathrm{mol}^{-1}\right)$ were the essential conditions for the standard working of the instrument.

\subsection{Oxidative Burst}

\subsubsection{Superoxide Anion Content}

The measurement of superoxide anion content was done after following Wu et al. [37] method. Crushing of $1 \mathrm{~g}$ plant material in $2 \%$ polyvinylpyrrolidone (PVP) and $0.5 \%$ Triton X-100 containing, $4 \mathrm{~mL} 50 \mathrm{mM}$ phosphate buffer (pH-7.8) was done. Then, they were spun at 10,000 rpm for $15 \mathrm{~min}$. 
After removing the $0.5 \mathrm{~mL}$ supernatant in separate tube, $0.5 \mathrm{~mL}$ of phosphate buffer and $0.1 \mathrm{~mL}$ hydroxylamine hydrochloride was mixed. Incubations at $25^{\circ} \mathrm{C}$ for $30 \mathrm{~min}$ were done. To this, $1 \mathrm{~mL}$ each of 1-naphthylamine and 3-aminobenzenesulphonic acid was supplemented and placed for $15 \mathrm{~min}$ at $26^{\circ} \mathrm{C}$. Optical density at $530 \mathrm{~nm}$ was further read.

\subsubsection{Hydrogen Peroxide Content}

The estimation of hydrogen peroxide content by Velikova et al. [38] proposed method was done. Homogenisation of $100 \mathrm{mg}$ of plant tissue in freshly prepared $0.1 \%$ Trichloroacetic acid (TCA) was done in cold motor pestle. They were then subjected to centrifuge at temperature of $4{ }^{\circ} \mathrm{C}$, at $10,000 \mathrm{rpm}$ for 20-25 min. The supernatant was removed in the separate tube and mixed with $0.5 \mathrm{~mL}$ of potassium phosphate buffer and $0.5 \mathrm{~mL}$ KI. Optical density at $390 \mathrm{~nm}$ was then recorded.

\subsubsection{Malondialdehyde Content}

Estimation of malondialdehyde (MDA) accumulation was conducted by Heath and Packer [39] method. To start with the measurement, $1 \mathrm{~g}$ of fresh plant material was macerated using freshly prepared $0.1 \% 5 \mathrm{~mL}$ TCA. Samples were centrifuged at $8000 \mathrm{rpm}$ at $4{ }^{\circ} \mathrm{C}$ for $15 \mathrm{~min} .1 \mathrm{~mL}$ supernatant was removed in a separate tube to which $4 \mathrm{~mL}$ of $0.5 \%$ thio-butyric acid (TBA) (made with $20 \%$ TCA) was combined. The incubations for 30-35 min at $90{ }^{\circ} \mathrm{C}$ were given by placing the tubes in water bath. After cooling the tubes, the optical density at $532 \mathrm{~nm}$ was read.

\subsection{Antioxidative Enzymes}

Specific activities of various antioxidative enzymes were evaluated by crushing $1 \mathrm{~g}$ plant tissue in $4 \mathrm{~mL} 100 \mathrm{mM}$ potassium phosphate buffer (pH7.0). Preparation of potassium phosphate buffer was done by combining four different ingredients i.e., $1 \mathrm{mM}$ EDTA, 5\% polyvinyl polypyrrolidone, $2 \mathrm{mM}$ phenylmethylsulfonyl fluoride and $0.5 \%$ triton-X-100. The crushed material was allowed for centrifugation for $20 \mathrm{~min}$ at 10,000 rpm.

\subsubsection{Superoxide dismutase Activity (EC.1.15.1.1)}

Specific activity of superoxide dismutase (SOD) was calculated by using standard protocol [40]. The ingredients of the reaction were $50 \mathrm{mM} \mathrm{Na}{ }_{2} \mathrm{CO}_{3}$ buffer, $1 \mathrm{mM}$ hydroxylamine hydrochloride ( $\left.\mathrm{pH} 6\right)$, $0.03 \%$ Triton-X 100, $24 \mu \mathrm{M}$ NBT, 0.1 Ethylenediaminetetraacetic acid (EDTA) and plant extract. The rise in absorbance at $540 \mathrm{~nm}$ was further noted.

\subsubsection{Guaiacol peroxidase Activity (EC. 1.11.1.7)}

Specific activity of guaiacol peroxidase (POD) was estimated by Pütter [41] method. The ingredients of the reaction were potassium phosphate buffer (20 mM with pH7.0), freshly prepared guaiacol solution $(10 \mathrm{mM}), 124 \mathrm{mM} \mathrm{H}_{2} \mathrm{O}_{2}$ and plant extract. The increase in absorbance was recorded at $436 \mathrm{~nm}$.

\subsubsection{Catalase Activity (EC.1.11.1.6)}

Specific activity of catalase (CAT) was examined according to Aebi [42] procedure. The ingredients of the reaction were potassium phosphate buffer (50 mM with pH7.0), $\mathrm{H}_{2} \mathrm{O}_{2}(20 \mathrm{mM})$ and plant extract. $\mathrm{H}_{2} \mathrm{O}_{2}$ dismutation declined optical density that was read at $240 \mathrm{~nm}$.

\subsubsection{Glutathione Peroxidase Activity (EC. 1.11.1.9)}

Specific activity of glutathione peroxidase (GPOX) was measured by procedure given by Flohé and Günzler [43].The components of reaction were phosphate buffer (50 mM; pH 7.0), Glutathione (0.15 mM), EDTA (0.5 mM), hydrogen peroxide(0.15 mM), NaN 3 (0.15 mM), 2.5 units/mL glutathione reductase (GR), NADPH $(0.15 \mathrm{mM})$ and plant extract. Absorbance at $340 \mathrm{~nm}$ was read. 


\subsubsection{Ascorbate Peroxidase Activity (EC.1.11.1.11)}

Specific activity of ascorbate peroxidase (APOX) was calculated by process suggested by Nakano and Asada [44]. The ingredients of reaction were ascorbate $(0.5 \mathrm{mM})$, potassium phosphate buffer $(50 \mathrm{mM})$ with $\mathrm{pH} 7.0$, hydrogen peroxide $(2 \mathrm{mM})$, and plant extract. Optical density at $290 \mathrm{~nm}$ was read.

\subsubsection{Dehydroascorbate Reductase Activity (EC. 1.8.5.1)}

Specific activity of dehydroascorbate reductase (DHAR) was evaluated by procedure propounded by Dalton et al. [45]. The reaction contained following ingredients; $50 \mathrm{mM}$ potassium phosphate buffer with $\mathrm{pH} 7$, dehydroascorbate $(0.25 \mathrm{mM})$, glutathione reduced $(2.5 \mathrm{mM})$ and plant extract. Optical density at $265 \mathrm{~nm}$ was then read.

\subsubsection{Glutathione-S-Transferase Activity (EC.2.5.1.18)}

Specific activity of glutathione-S-transferase (GST) was quantified by method offered by Habig and Jakoby [46]. Reaction was initiated by combining $20 \mathrm{mM}$ potassium phosphate buffer with $\mathrm{pH} 7.5$, glutathione reduced $(20 \mathrm{mM}), \mathrm{cDNB}(15 \mathrm{mM})$ and plant extract. Optical density at $340 \mathrm{~nm}$ was noted.

\subsubsection{Glutathione Reductase Activity (EC.1.6.4.2)}

Specific activity of GR was estimated by process presented by Carlberg and Mannervik [47]. The ingredients of reaction were $20 \mathrm{mM}$ potassium phosphate buffer with pH7, $1 \mathrm{mM} \mathrm{GSSG}, 1 \mathrm{mM}$ EDTA, $0.2 \mathrm{mM}$ NADPH and plant extract. After combining all, absorbance at $340 \mathrm{~nm}$ was taken.

\subsubsection{Polyphenol oxidase Activity (EC. 1.14.18.1)}

Specific activity of polyphenol oxidase (PPO) enzyme was measured by Kumar and Khan [48] method. The reaction ingredients were $50 \mathrm{mM}$ potassium phosphate buffer with $\mathrm{pH} 6,80 \mathrm{mM}$ catechol and enzyme extract. They were combined and sited for 5-10 min, after which $\mathrm{H}_{2} \mathrm{SO}_{4}(3.5 \mathrm{~N})$ was added. Absorbance at $495 \mathrm{~nm}$ was then recorded.

\subsection{Non-Enzymatic Antioxidants}

To estimate the levels of non-enzymatic antioxidants, fresh plant tissue was grounded in $50 \mathrm{mM}$ of $4 \mathrm{~mL}$ Tris Buffer with $\mathrm{pH} 10$ using cold, sterile and autoclaved motor pestle. After that, centrifugation in cold centrifuge $\left(4^{\circ} \mathrm{C}\right)$ at 10,000 rpm was done for 15-20 min. Collection of supernatant in other tubes was done to quantify antioxidants (glutathione, ascorbic acid and tocopherol).

\subsubsection{Glutathione Content}

Estimation of glutathione content was done through standard protocol offered by Noctor and Foyer [49]. For this, combination of following contents, $100 \mu \mathrm{L}$ supernatant, $50 \mu \mathrm{L}$ DTNB, $4 \mathrm{~mL}$ absolute alcohol and $1000 \mu \mathrm{L}$ Tris buffer were taken in a tube and placed under room temperature for $10 \mathrm{~min}$. The tubes were vortexed for $10 \mathrm{~min}$ until a yellow coloured product is formed. Optical density at $412 \mathrm{~nm}$ was read.

\subsubsection{Ascorbic Acid Content}

Estimation of ascorbic acid was conducted through procedure opted by Roe and Kuether [50]. For this, combination of $1 \mathrm{~mL}$ supernatant, $1 \mathrm{~mL}$ freshly prepared $50 \%$ TCA and $0.5 \mathrm{~mL}$ DPNH was done. The tubes were shaken vigorously after which they were incubated at room temperature for $4 \mathrm{~h}$. The osazones crystals produced were dissolved in cold sulphuric acid. Incubation in ice for $20 \mathrm{~min}$ was given and absorbance at $540 \mathrm{~nm}$ was read.

\subsubsection{Tocopherol Content}

Estimation of tocopherol content was done by Martinek [51] established protocol. For this, $500 \mu \mathrm{L}$ homogenate was combined to $500 \mu \mathrm{L}$ distilled water, $500 \mu \mathrm{L}$ absolute ethanol prepared by adding $0.12 \%$ 
$\mathrm{FeCl}_{3} 6 \mathrm{H}_{2} \mathrm{O}$. The tubes were shaken vigorously until the protein crystals were developed. Crystals were dissolved in $500 \mu \mathrm{L}$ xylene and vortexed for $2 \mathrm{~min}$. The layer formed on upper phase was combined to TPTZ in separate tube and optical density at $600 \mathrm{~nm}$ was read.

\subsection{Phenolic Compounds}

\subsubsection{Total Phenols}

Estimation of total phenol content was conducted through method examined by Singleton and Rossi [52]. For this, $500 \mathrm{mg}$ oven dried sample was grounded in $60 \%$ ethanol, after which it was warmed at $65{ }^{\circ} \mathrm{C}$ using water bath for $20 \mathrm{~min}$. Samples were filtered by Whatmann (GE Healthcare Life Sciences, Maidstone, UK) filter paper till the residue was left behind. $100 \mathrm{~mL}$ of total sample volume was maintained by $60 \%$ ethanol. There was $2 \mathrm{~mL}$ of this sample mixed in another tube containing $8 \mathrm{~mL}$ FC reagent and $8 \mathrm{~mL}$ sodium carbonate. Incubation for $4 \mathrm{~h}$ was given followed by measuring optical density at $765 \mathrm{~nm}$. (Standard curve prepared by gallic acid).

\subsubsection{Total Flavonoids}

Estimation of total flavonoids was conducted by standard procedure given by [53]. For this, $100 \mathrm{mg}$ of dried sample was macerated in $4 \mathrm{~mL}$ absolute alcohol. The preparation of extractant was done by combining $3 \mathrm{~mL}$ each of $5 \% \mathrm{NaNO}_{2}, 5 \% \mathrm{AlCl}_{3}$ and distilled water. $1 \mathrm{~mL}$ of above prepared extractant was then combined to $2 \mathrm{~mL}$ sodium hydroxide and $2.5 \mathrm{~mL}$ of distilled water in sample tube. Incubation was done for $10 \mathrm{~min}$ followed by measuring optical density at $510 \mathrm{~nm}$ (Standard used: Rutin).

\subsubsection{Total Anthocyanins}

Estimation of total anthocyanins was done through procedure followed by Mancinelli [54]. For this, $1000 \mathrm{mg}$ of plant material was crushed in reagent prepared by combining absolute methanol, distilled water and hydrochloric acid in the ratio of 78:20:2. The sample was incubated under cold conditions $\left(4{ }^{\circ} \mathrm{C}\right.$ ) for $12 \mathrm{~h}$ and spun at $14,000 \mathrm{rpm}$ for $20 \mathrm{~min}$. Absorbance at 530 and $657 \mathrm{~nm}$ was read to calculate the anthocyanin content.

\subsection{Osmoprotectants}

\subsubsection{Total Osmolytes}

Estimation of total osmolytes was done with Vapour Pressure Osmometer (Vapro 5600, ELITechGroup, Paris, France). The fresh plant samples were stored in liquid nitrogen and thawed for sap extraction using syringe. The sap was collected for further analysis. Only $10 \mu \mathrm{L}$ of sap was used for analysis and loaded directly on filter paper discs kept upon the instrument. Calibration of instrument was done using Sodium chloride standard kits with 1000, 290 and 100 mOsm osmolarities that come along with the instrument. Values displayed on the instrument were noted after maintaining room temperature conditions of $22,23^{\circ} \mathrm{C}$.

\subsubsection{Total Carbohydrates}

Total carbohydrates were calculated through the Hedge et al. [55] procedure. For this, $100 \mathrm{mg}$ sample was warmed in $4 \mathrm{~mL}$ of $2.6 \mathrm{~N} \mathrm{HCl}$ for $5 \mathrm{~h}$. Incubations at room temperature were given followed by the addition of sodium carbonate to offset the reaction. A total volume of $30 \mathrm{~mL}$ was maintained by addition of $25 \mathrm{~mL}$ distilled water. There was $4 \mathrm{~mL}$ of anthrone reagent taken in the separate tube to which $1 \mathrm{~mL}$ of above sample was added and subjected to boil for $15 \mathrm{~min}$. Samples were cooled and optical density at $630 \mathrm{~nm}$ was read (D-glucose: standard).

\subsubsection{Total Reducing Sugars}

The analysis of total reducing sugars was done by method provided by Miller [56]. For this, $100 \mathrm{mg}$ dried and finely powdered sample was crushed in $80 \%$ absolute alcohol. Preparation of DNSA was done 
through combination of $0.2 \mathrm{~g}$ phenol crystals and $0.05 \mathrm{~g} \mathrm{Na}_{2} \mathrm{SO}_{3}$ under cold conditions. In total, $3 \mathrm{~mL}$ of this freshly prepared reagent was added to $1 \mathrm{~mL}$ of above supernatant and $40 \% \mathrm{KNaC}_{4} \mathrm{H}_{4} \mathrm{O}_{6} \cdot 4 \mathrm{H}_{2} \mathrm{O}$. Incubation for $2 \mathrm{~min}$ was given at room temperature to record the optical density at $510 \mathrm{~nm}$.

\subsubsection{Trehalose Content}

Estimation of trehalose content was done through Trevelyan and Harrison [57] assay. The analysis was begun by crushing $500 \mathrm{mg}$ oven dried sample in $80 \%$ ethanol and further centrifuged under cold conditions of $4{ }^{\circ} \mathrm{C}$ at $10,000 \mathrm{rpm}$ for $20 \mathrm{~min}$. The components of reaction were combined by adding $100 \mu \mathrm{L}$ of above extractant, $4 \mathrm{~mL}$ anthrone reagent and $3 \mathrm{~mL}$ freshly prepared TCA. Optical density at $620 \mathrm{~nm}$ was read after the formation of deep yellow coloured product (D-glucose: standard).

\subsubsection{Glycine Betaine Content}

The measurement of glycine betaine (GB) content was predicted by Grieve and Grattan [58] protocol. To begin with the analysis, $500 \mathrm{mg}$ dried sample was crushed in $0.05 \%$ toluene and $4 \mathrm{~mL}$ double distilled water which was then incubated for $24 \mathrm{~h}$. Samples were filtered through filters with $0.2 \mu \mathrm{m}$ pore size. The reaction components were mixed by combining $500 \mu \mathrm{L}$ supernatant, $1000 \mu \mathrm{L}$ $3 \mathrm{~N} \mathrm{HCl}$ and $100 \mu \mathrm{L}$ potassium iodide. Incubations of samples were done in ice for $4 \mathrm{~h}$. To the reaction tubes, $3 \mathrm{~mL}$ chilled water and $8 \mathrm{~mL}$ 1,2-dichloroethane was mixed. The tubes were vortexed till the formation of two different layers. The above layer was thrown, and bottom pink layer was kept for analysis. Optical density at $365 \mathrm{~nm}$ was then read (Standard: betaine hydrochloride).

\subsubsection{Proline Content}

Estimation of proline content was done through Bates et al. [59] analysis method. For this, $500 \mathrm{mg}$ sample was crushed in $10 \mathrm{~mL} \mathrm{3 \%} \mathrm{sulphosalicylic} \mathrm{acid.} \mathrm{Centrifugation} \mathrm{of} \mathrm{sample} \mathrm{tubes} \mathrm{at} \mathrm{10,000} \mathrm{rpm}$ for 15-20 min was done. Sample tubes containing $2 \mathrm{~mL}$ supernatant was separated and combined to $3 \mathrm{~mL}$ ninhydrin reagent and $3 \mathrm{~mL}$ glacial acetic acid. The tubes were heated to $100{ }^{\circ} \mathrm{C}$ and placed in ice after $5 \mathrm{~min}$ to counterbalance the reaction. Later, $5 \mathrm{~mL}$ toluene was further mixed to it and tubes were vortexed for $3 \mathrm{~min}$. The red toluene layer was formed of which the optical density at $520 \mathrm{~nm}$ was read (Standard: L-proline).

\subsubsection{Free Amino Acid Content}

Estimation of free amino acid content was done via Lee and Takahashi [60] method. To begin with, $100 \mathrm{mg}$ dried sample was crushed using $4 \mathrm{~mL}$ absolute ethanol and warmed at $50{ }^{\circ} \mathrm{C}$ for $10 \mathrm{~min}$ using water bath. The reaction tubes were vortexed for $5 \mathrm{~min}$. Later, freshly formed ninhydrin reagent was combined with $200 \mu \mathrm{L}$ sample and heated for $5 \mathrm{~min}$. Optical density at $570 \mathrm{~nm}$ was taken after the formation of blue colour.

\subsection{Organic Acid Profiling}

Organic acid profiling was done through following Chen et al. [61] method with slight modifications. To begin with the analysis, $50 \mathrm{mg}$ dried crushed sample was taken to which $500 \mu \mathrm{L}$ absolute methanol and $500 \mu \mathrm{L} 2.5 \mathrm{~N} \mathrm{HCl}$ was pooled. Sample tubes were then placed in shaker for $5 \mathrm{~h}$, and centrifuged under cold conditions $\left(4^{\circ} \mathrm{C}\right)$ at $10,000 \mathrm{rpm}$ for $10 \mathrm{~min}$. The residue was left behind and above liquid was transferred into another tube to which $0.3 \mathrm{~mL}$ methanol and $0.1 \mathrm{~mL} 50 \%$ conc. sulphuric acid was combined, vortexed and incubated for $10 \mathrm{~h}$ at $65^{\circ} \mathrm{C}$ in water bath. Sample tubes were cooled at $28^{\circ} \mathrm{C}$ and $800 \mu \mathrm{L}$ chloroform and $400 \mu \mathrm{L}$ double distilled water mixed into it. Vortexing was done till the formation of two different layers. The basal layer was collected for organic acid analysis by GC-MS. The system (Shimadzu GC-MS-Q2010Plus, Japan) required $2 \mu \mathrm{L}$ sample for analysis. Standard conditions of the instrument were: (i) for GC: helium carrier gas, column with flow rate of $1.7 \mathrm{~mL} / \mathrm{min}$, analytical column with length of $30 \mathrm{~m}$, ID- $0.025 \mathrm{~mm}$ and $\mathrm{DB}, 5 \mathrm{~ms}$, temperature of $125^{\circ} \mathrm{C}$ and $25^{\circ} \mathrm{C} / \mathrm{min}$; 
(ii) for MS: ion source with temp $200{ }^{\circ} \mathrm{C}$ and detection mode is relative. The organic acid quantification was carried out by comparing mass spectra or peaks with National Institute of Standard and Technology and Wiley 7 Library.

\subsection{Statistical Analysis}

The morphological, physiological and biochemical data was statistically tested through the self-built program in Microsoft Excel (Microsoft Office Excel 2007, Albuquerque, New Mexico, USA). Results in the form of mean \pm standard deviation (SD) (level of significance checked at $p \leq 0.05$ and 0.01 ) were presented. Null hypothesis $\left(\mathrm{H}_{0}\right)$ was verified by two-way ANOVA (analysis of variance). Data was also confirmed with Tukey's multiple comparison test and HSD (honestly significant difference).

\section{Results}

\subsection{Effect of Biocontrol Agents on Growth Parameters of PPN Infected L. esculentum Plants}

The ramifications of microbial strains (P. aeruginosa (M1) and B. gladioli (M2) on morphological parameters of 45-days old L. esculentum plants raised under PPN infestation was investigated in terms of root length, shoot length, biomass (fresh weight, dry weight) and number of galls. The results indicated a remarkable reduction in the root length and shoot length of plants by 43.2 and $21.5 \%$ relative to control plants. The decline in the plant biomass of infected plants (fresh weight (35.1\%) and dry weight (47.6\%)) was also reported. However, after the inoculation of $P$. aeruginosa (M1) the enhancement in the root length, shoot length, fresh weight and dry weight was noted by 73.3, 54.3, 33.2, and $105.4 \%$, respectively. The supplementation of B. gladioli (M2) in infected plants also maximised the root length (51.6\%), shoot length (69.7\%), fresh weight $(49.6 \%)$ and dry weight $(110.5 \%)$ when compared to PPN experimental plants. Furthermore, the number of galls were also measured in PPN inoculated plants. The gall numbers (27) were counted in plants inhabited with nematodes, and their significant reduction was noted in the plants supplemented with rhizobacterial strains. Reduction of $28.06 \%$ was observed after P. aeruginosa (M1) addition while reduction to $19.5 \%$ was seen after B. gladioli (B2) treatment in contrast to experimental controls (Table 1).

Table 1. Effect of M1 (109 cells $/ \mathrm{mL})$ and M2 $\left(10^{9}\right.$ cells $\left./ \mathrm{mL}\right)$ on: ${ }^{a}$ root length, ${ }^{\mathrm{b}}$ shoot length, ${ }^{\mathrm{c}}$ fresh weight, $\mathrm{d}$ dry weight, ${ }^{\mathrm{e}}$ number of galls in 45-days old Lycopersicon esculentum plants under plant parasitic nematodes (PPN) infection.

\begin{tabular}{|c|c|c|c|c|c|}
\hline Treatments & $\begin{array}{l}\text { Root Length }(\mathrm{cm}) \\
(\text { Mean } \pm \text { SD) }\end{array}$ & $\begin{array}{l}\text { Shoot Length }(\mathrm{cm}) \\
\quad(\text { Mean } \pm \text { SD) }\end{array}$ & $\begin{array}{c}\text { Fresh Weight (g/plant) } \\
(\text { Mean } \pm \text { SD) }\end{array}$ & $\begin{array}{l}\text { Dry Weight (g/plant) } \\
(\text { Mean } \pm \text { SD) }\end{array}$ & $\begin{array}{l}\text { No. of Galls } \\
\text { (Mean } \pm \text { SD) }\end{array}$ \\
\hline $\mathrm{CN}$ & $15.78 \pm 0.2505^{b}$ & $22.13 \pm 0.4635^{d}$ & $4.69 \pm 0.2495^{\mathrm{a}}$ & $1.96 \pm 0.1334^{b, c}$ & 0 \\
\hline $\mathrm{N}$ & $8.96 \pm 0.6502^{d}$ & $17.36 \pm 0.6036^{\mathrm{e}}$ & $3.04 \pm 0.2502^{c}$ & $1.02 \pm 0.1251^{\mathrm{d}}$ & $27.33 \pm 1.527^{\mathrm{a}}$ \\
\hline M1 & $17.42 \pm 0.3651^{b}$ & $24.54 \pm 0.8015^{c}$ & $4.71 \pm 0.1182^{\mathrm{a}}$ & $1.93 \pm 0.0695^{b, c}$ & 0 \\
\hline $\mathrm{M} 1+\mathrm{N}$ & $15.53 \pm 0.7946^{b, c}$ & $26.80 \pm 1.1654^{b}$ & $4.05 \pm 0.2501^{b}$ & $2.10 \pm 0.1100^{a, b}$ & $19.66 \pm 0.1 .527^{b}$ \\
\hline M2 & $19.50 \pm 0.7379^{a}$ & $22.38 \pm 0.4178^{c, d}$ & $4.21 \pm 0.1608^{a, b}$ & $2.02 \pm 0.1481^{b}$ & 0 \\
\hline $\mathrm{M} 2+\mathrm{N}$ & $13.59 \pm 1.1119^{c}$ & $29.47 \pm 1.0726^{a}$ & $4.55 \pm 0.1574^{\mathrm{a}}$ & $2.15 \pm 0.099^{a}$ & $22 \pm 1^{b}$ \\
\hline F-ratio $_{(\mathrm{df} 1,12)} \mathrm{T}$ & $210.9^{* *}$ & $15.85^{* *}$ & $45.38^{* *}$ & $15.39 * *$ & $2520.5^{* *}$ \\
\hline F-ratio $_{(\mathrm{df} 2,12)} \mathrm{D}$ & $68.13^{* *}$ & $110.6^{* *}$ & $12.27 * *$ & $46.41^{* *}$ & $27.54 * *$ \\
\hline F-ratio $_{(\mathrm{df} 2,12)} \mathrm{T} \times \mathrm{D}$ & $20.65 *$ & $80.30 * *$ & $31.75 * *$ & $43.17^{* *}$ & $24.52 * *$ \\
\hline HSD & 1.949 & 2.217 & 0.593 & 0.321 & 2.665 \\
\hline
\end{tabular}

Data is presented as means of three replicates \pm SD (standard deviation) and HSD values. F ratio values, ${ }^{*}$ indicates significance at $p \leq 0.05$ and ${ }^{* *}$ indicates significance at $p \leq 0.01$ ). Different letters on the graphs indicate that mean values of treatments are significantly different at $p<0.5$ according to Tukey's multiple comparison test. CN: Control, $\mathrm{N}$ : Nematode, M1: Pseudomonas aeruginosa, M2: Burkholderia gladioli.

\subsection{Effect of Biocontrol Agents on Photosynthetic Pigments of PPNPPN Infected L. esculentumPlants}

The plant pigments were determined in terms of total chlorophyll, carotenoid and xanthophyll. It was evaluated that level of total chlorophyll was reduced to $19.7 \%$ in plants raised with nematode infestation as compared to experimental controls. But, supplementation of P. aeruginosa (M1) to nematode infected plants, led to uplifted levels of total chlorophyll from 19.7 to $68.5 \%$ respectively. 
Also, the inoculation of B. gladioli (M2) in infected plants stimulated the total chlorophyll content in plants by $91.1 \%$ respectively. The levels of carotenoids estimated, showed lowered levels by $60.9 \%$ in plants infected with nematodes relative to controls. After the application of P. aeruginosa (M1), a sharp enhancement in the level of carotenoids by $183 \%$ was noticed in nematode infested plants and by $220 \%$ after the inoculation of B. gladioli (M2). In addition, the levels of xanthophyll were also minimised by $33 \%$ in plants raised under nematode treated soils in contrast to control. A remarkable stimulation in xanthophyll content was measured by 56.4 and $86.7 \%$, after the inoculation of $P$. aeruginosa (M1) and B. gladioli (M2) respectively, in nematode infested plants when compared with experimental controls (Figure 1).
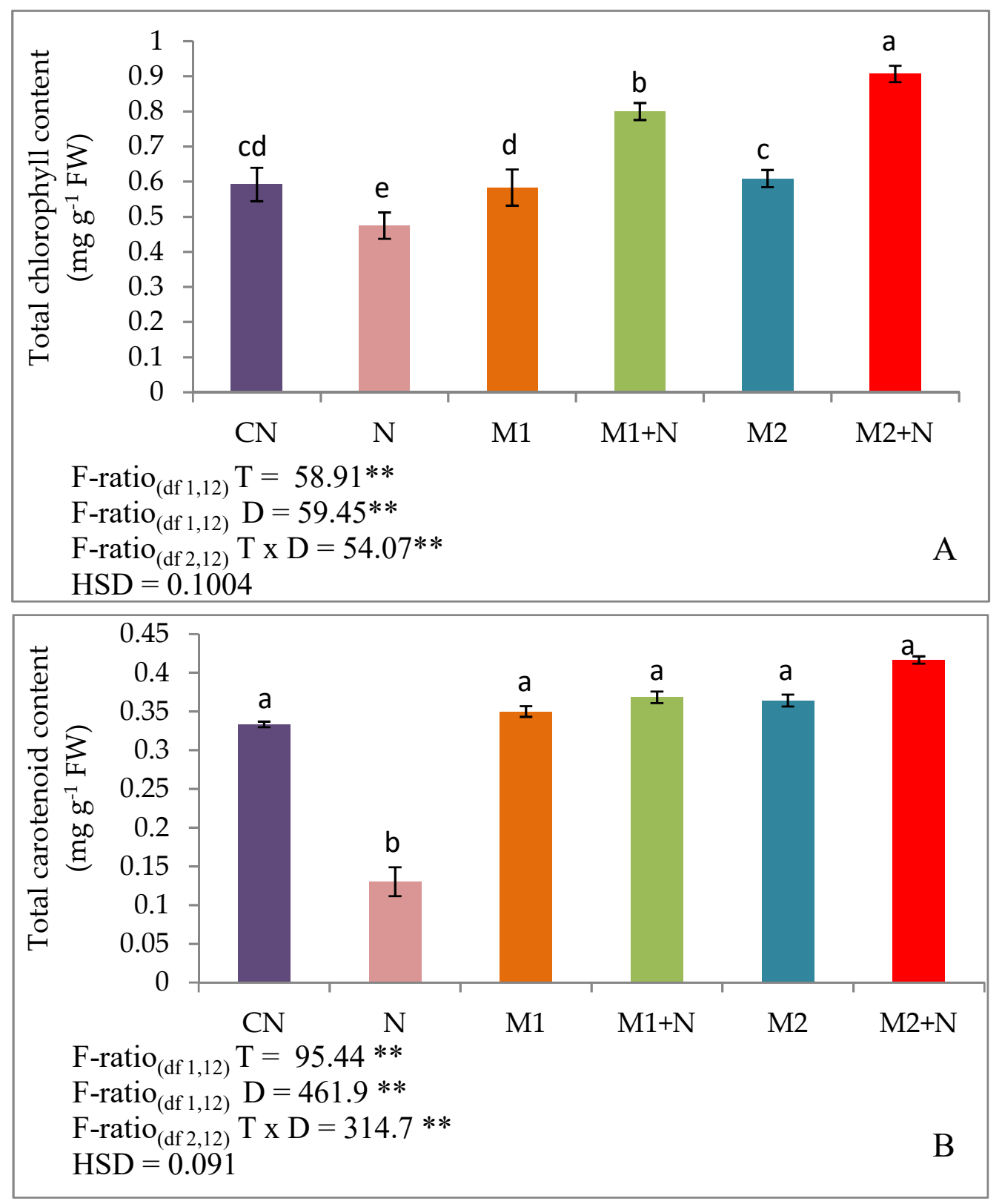

Figure 1. Cont. 


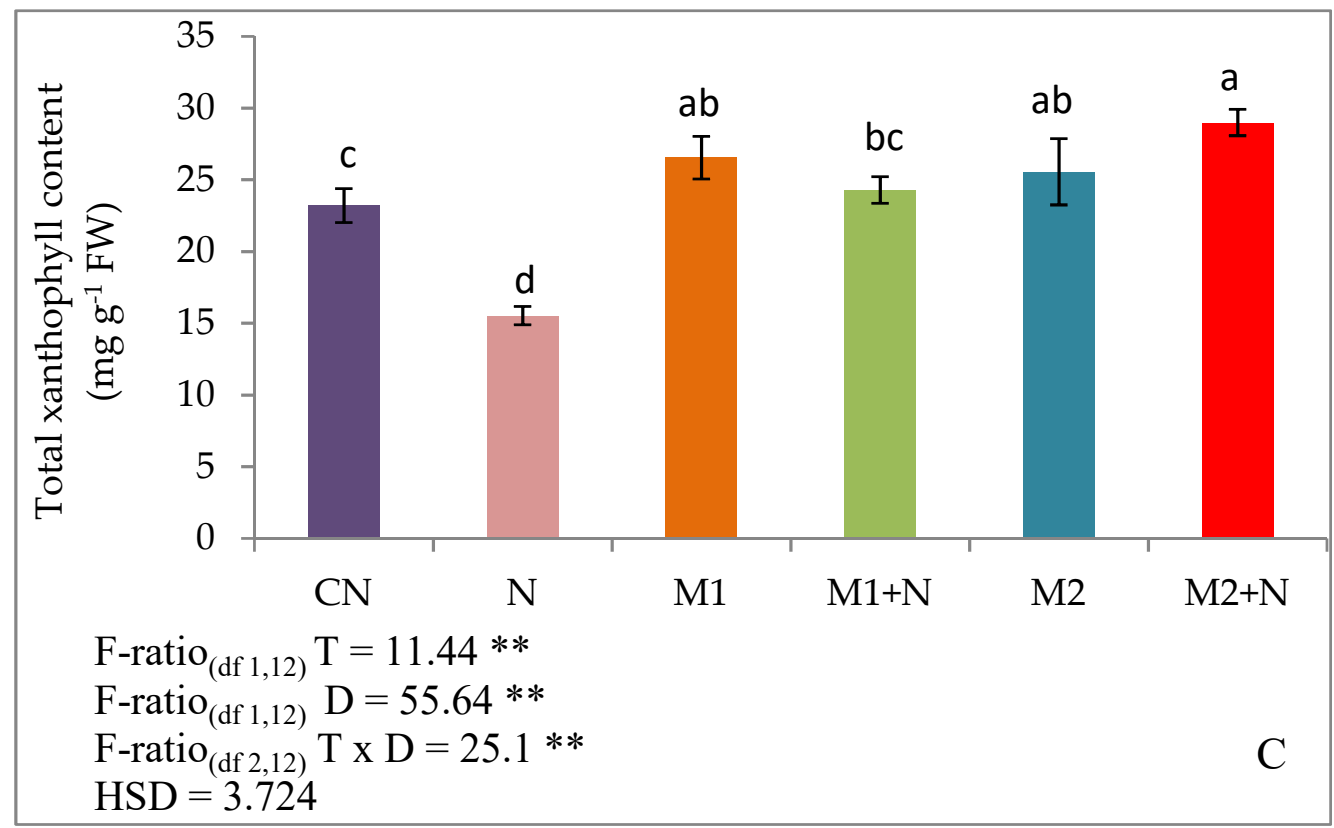

Figure 1. Effect of M1 $\left(10^{9}\right.$ cells $\left./ \mathrm{mL}\right)$ and $\mathrm{M} 2\left(10^{9}\right.$ cells $\left./ \mathrm{mL}\right)$ on photosynthetic pigments (A) Total Chlorophyll content (B) Total Carotenoid content (C) Total Xanthophyll content in 45-days old L. esculentum under PPN infection. Data is presented as means of three replicates $\pm \mathrm{SD}$ and honestly significant difference (HSD) values. F ratio values, ${ }^{*}$ indicates significance at $p \leq 0.05$ and ${ }^{* *}$ indicates significance at $p \leq 0.01$ ). Different letters on the table indicate that mean values of treatments are significantly different at $p<0.5$ according to Tukey's multiple comparison test.

\subsection{Effect of Biocontrol Agents on Gas Exchange Parameters of PPN Infected L. esculentum Plants}

The results depicted an alteration in the gas exchange parameters of plants raised under the influence of nematode infection and bacterial strains. The results displayed a noticeable reduction in net photosynthetic rate, stomatal conductance, intercellular $\mathrm{CO}_{2}$ and transpiration rate by 33.9, 31.6, 11.3 and $40.3 \%$ respectively, in 45-days old PPN infected plants. Supplementation of P. aeruginosa (M1) in infected plants led to an upregulation in all these gas exchange parameters. The inclination in the net photosynthetic rate, stomatal conductance, intercellular $\mathrm{CO}_{2}$ and transpiration rate was revealed by $32.7,80.2,8.64$ and $30 \%$ respectively, after inoculations in the infected plants. The inoculation with B. gladioli (M2) also enhanced the activities of net photosynthetic rate, stomatal conductance, intercellular $\mathrm{CO}_{2}$ and transpiration rate by $87,88.5,24.4$ and $46 \%$ respectively, in infected plants in comparison to experimental controls (Table 2).

\subsection{Effect of Biocontrol Agents on Oxidative Damage in PPN Infected L. esculentum Plants}

The oxidative damage was assessed by estimating the levels of oxidative stress markers namely, superoxide anion, $\mathrm{H}_{2} \mathrm{O}_{2}$ and MDA. It was revealed in the present investigation that PPN infestation in 45-days old plants inclined the levels of superoxide anion (48.7\%), $\mathrm{H}_{2} \mathrm{O}_{2}(195.1 \%)$ and MDA content $(168.7 \%)$ relative to infected control plants. The inoculation of P. aeruginosa (M1) waned off the superoxide anion levels by $9.98 \%, \mathrm{H}_{2} \mathrm{O}_{2}$ levels by $19.4 \%$ and MDA levels by $27.3 \%$ in nematode infected L. esculentum plants. However, the amendment of PPN infected plants with B. gladioli (M2) also declined the superoxide anion, $\mathrm{H}_{2} \mathrm{O}_{2}$ and MDA levels by 18.7, 29.1 and 20.6\%, respectively (Figure 2). 
Table 2. Effect of M1 ( $10^{9}$ cells $\left./ \mathrm{mL}\right)$ and $\mathrm{M} 2\left(10^{9}\right.$ cells $\left./ \mathrm{mL}\right)$ on gas exchange parameters ${ }^{\text {a }}$ net photosynthetic rate, ${ }^{\mathrm{b}}$ stomatal conductance, ${ }^{\mathrm{c}}$ intracellular $\mathrm{CO}_{2},{ }^{\mathrm{d}}$ transpiration rate in 45 -days old L. esculentum under PPN infection.

\begin{tabular}{|c|c|c|c|c|}
\hline Treatments & 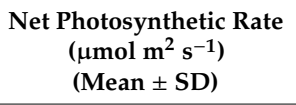 & $\begin{array}{c}\text { Stomatal Conductance } \\
\left(\mathrm{mmol} \mathrm{CO}_{2} \mathrm{~m}^{2} \mathrm{~s}^{-1}\right) \\
(\text { Mean } \pm \mathrm{SD})\end{array}$ & $\begin{array}{c}\text { Intracellular } \mathrm{CO}_{2} \text { Rate } \\
\left.(\mu \mathrm{mol} \mathrm{mol})^{1}\right) \\
(\text { Mean } \pm S D)\end{array}$ & $\begin{array}{c}\text { Transpiration Rate } \\
\left(\mathrm{mmol} \mathrm{m}^{2} \mathrm{~s}^{-1}\right) \\
(\text { Mean } \pm \mathrm{SD})\end{array}$ \\
\hline $\mathrm{CN}$ & $25.54 \pm 0.9492^{c}$ & $0.474 \pm 0.016^{\mathrm{d}}$ & $436 \pm 8.426^{b, c}$ & $2.453 \pm 0.115^{b}$ \\
\hline $\mathrm{N}$ & $16.87 \pm 0.3952^{\mathrm{e}}$ & $0.324 \pm 0.0075^{\mathrm{e}}$ & $386.3 \pm 6.760^{d}$ & $1.463 \pm 0.1150^{\mathrm{d}}$ \\
\hline M1 & $28.33 \pm 0.8304^{b}$ & $0.524 \pm 0.0125^{c}$ & $455.6 \pm 5.511^{b}$ & $2.75 \pm 0.1178^{a, b}$ \\
\hline $\mathrm{M} 1+\mathrm{N}$ & $22.44 \pm 0.6165^{\mathrm{d}}$ & $0.584 \pm 0.0117^{b}$ & $419.7 \pm 8.891^{\mathrm{c}}$ & $1.903 \pm 0.1078^{c}$ \\
\hline M2 & $27.73 \pm 0.535^{b, c}$ & $0.496 \pm 0.0091^{\mathrm{c}, \mathrm{d}}$ & $442.3 \pm 3.146^{b}$ & $2.97 \pm 0.090^{\mathrm{a}}$ \\
\hline $\mathrm{M} 2+\mathrm{N}$ & $31.55 \pm 1.2690^{\mathrm{a}}$ & $0.611 \pm 0.0123^{\mathrm{a}}$ & $480.9 \pm 8.603^{a}$ & $2.13 \pm 0.1418^{c}$ \\
\hline F-ratio $_{(\mathrm{df} 1,12)} \mathrm{T}$ & $86.69 * *$ & 2.256 & $21.27^{* *}$ & $266.5^{* *}$ \\
\hline F-ratio $_{(\mathrm{df} 2,12)} \mathrm{D}$ & $159.09^{* *}$ & $336.04 * *$ & $74.02 * *$ & $40.46^{* *}$ \\
\hline F-ratio $_{(\mathrm{df} 2,12)} \mathrm{T} \times \mathrm{D}$ & $96.33 * *$ & $205.72 * *$ & $65.39 * *$ & 1.846 \\
\hline HSD & 2.245 & 0.0326 & 19.702 & 0.3171 \\
\hline
\end{tabular}

Data is presented as means of three replicates \pm SD and HSD values. F ratio values, ${ }^{*}$ indicates significance at $p \leq 0.05$ and ${ }^{* *}$ indicates significance at $p \leq 0.01$ ). Different letters on the table indicate that mean values of treatments are significantly different at $p<0.5$ according to Tukey's multiple comparison.
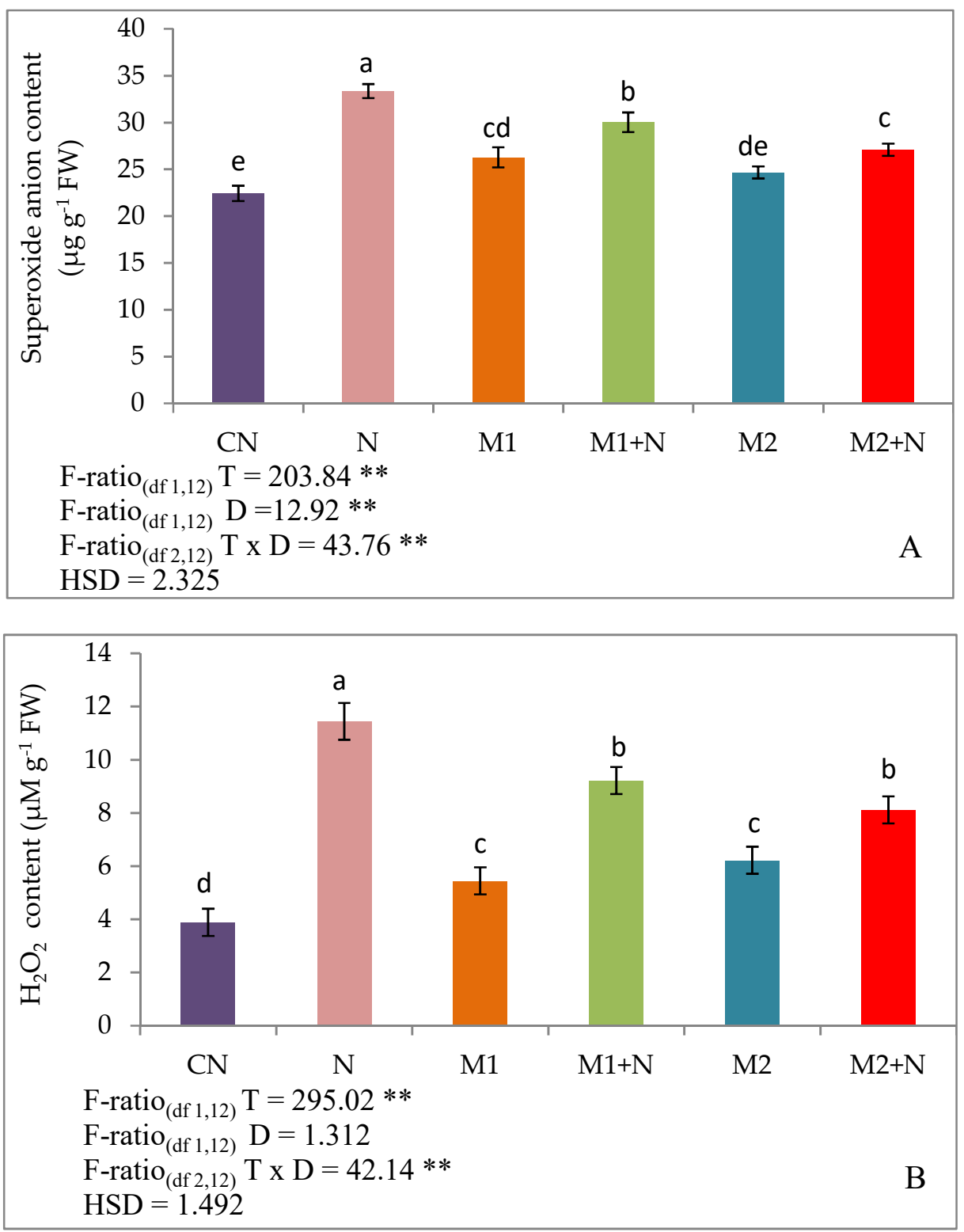

Figure 2. Cont. 


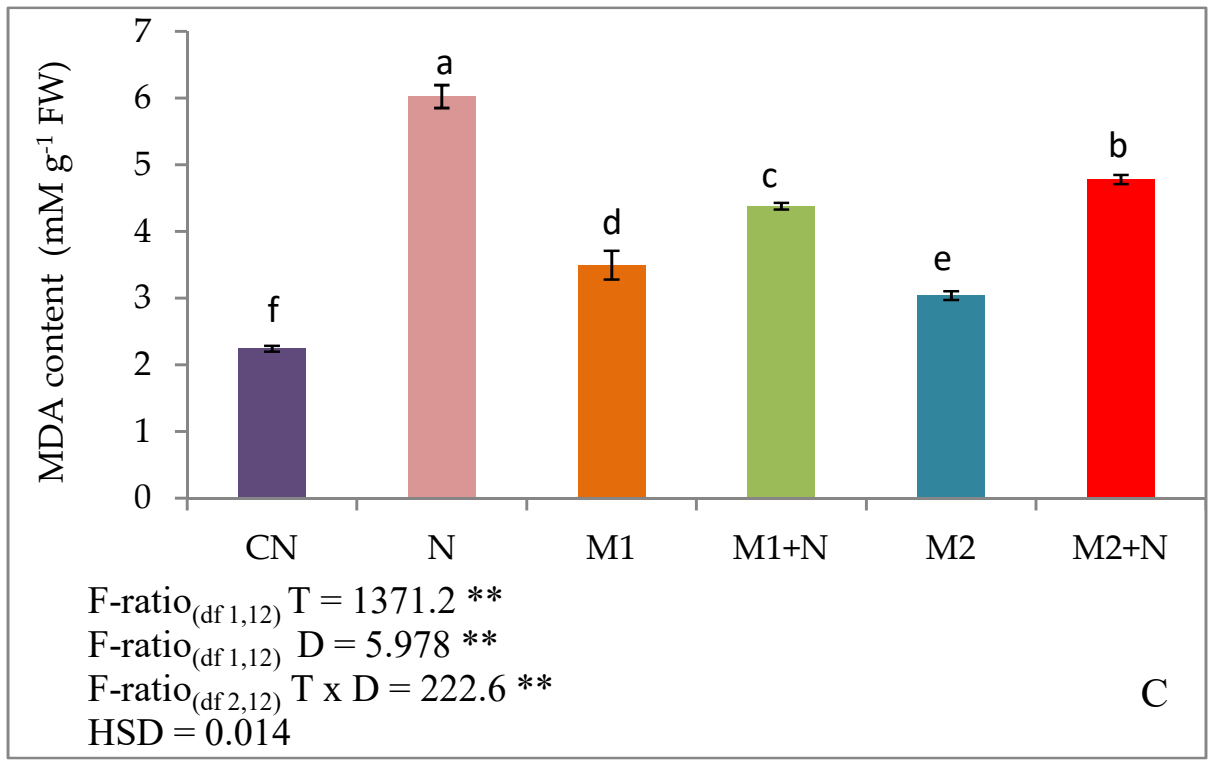

Figure 2. Effect of M1 (10 ${ }^{9}$ cells/mL) and M2 (10 ${ }^{9}$ cells/mL) on: (A) Superoxide Anion content, (B) Hydrogen peroxide content and (C) malondialdehyde (MDA) content in 45-days old L. esculentum plants under PPN infection. Data is presented as means of three replicates \pm SD and HSD values. F ratio values, ${ }^{*}$ indicates significance at $p \leq 0.05$ and ${ }^{* *}$ indicates significance at $p \leq 0.01$ ). Different letters on the graphs indicate that mean values of treatments are significantly different at $p<0.5$ according to Tukey's multiple comparison test.

\subsection{Effect of Biocontrol Agents on Antioxidative Enzymes Activities of PPN Infected L. esculentum Plants}

The activities of different antioxidative enzymes; SOD, POD, CAT, GR, GST, APOX, GPOX, DHAR and PPO were measured in 45-days old nematode infected L. esculentum plants. The results showed an elevation in the activities of SOD (34.6\%), POD (100.5\%), CAT (31.1\%), APOX (13.6\%), GPOX (42.7\%), DHAR $(9.98 \%)$, GST (26.3\%), GR (68\%) and PPO (19.2\%) in PPN infected plants as compared to untreated plants. The amendment of PPN infected plants with P. aeruginosa(M1) further upregulated the activities of SOD, POD, CAT and APOX by 17.3, 30.1, 10.82 and 15.48\% respectively. Also, the activities of GPOX, GST, DHAR, GR and PPO were also further stimulated in infected plants on treatment with P. aeruginosa (M1) by $6.98,38.5,16.07,1.74$ and $64.4 \%$ respectively. Moreover, the augmentation of B. gladioli (M2) also triggered the SOD, POD, CAT and APOX by 9.4, 12.8, 7.83, 18.1\% respectively in plants raised under PPN infection. Along with this, GST, GPOX, GR, DHAR and PPO were also recorded to be elevated by $61.8,19.16,7.29,21.76$ and $46.02 \%$ respectively in plants in the presence of B. gladioli (Table 3).

\subsection{Effect of Biocontrol Agents on Non-Enzymatic Antioxidants of PPNInfected L. esculentum Plants}

The results pertaining to non-enzymatic antioxidants, glutathione, ascorbic acid, and tocopherol were found to be modulated in plants subjected to nematode infection and microbial treatment. A remarkable stimulation in the non-enzymatic antioxidants was estimated in the nematode infected plants. The glutathione content was raised by $51.2 \%$ in nematode infested plants relative to experimental controls. This was further accelerated after the addition of P. aeruginosa (M1) in infected plants and by 7.11 and $16.9 \%$ after the treatment of B. gladioli (M2) respectively. A similar observation was recorded for ascorbic acid levels where an escalation in the ascorbic acid levels was noted by $36.9 \%$ in infested plants while that of controls. This was further augmented by P. aeruginosa (M1) and B. gladioli (M2) independently, after which an enhancement in the ascorbic acid levels by $10.9 \%$ and $17.2 \%$ were reported. Another antioxidant, tocopherol was also estimated and found to be stimulated by $37.3 \%$ in PPN infested plants. Moreover, an inoculation of P. aeruginosa (M1) raised the tocopherol content in PPN affected plants by 9 and $15.67 \%$ by amendment with B. gladioli (M2) respectively (Figure 3). 
Table 3. Effect of M1 ( $10^{9}$ cells $\left./ \mathrm{mL}\right)$ and M2 ( $10^{9}$ cells/mL) on: SOD, POD, CAT, GPOX, APOX, DHAR, GST, GR, PPO in 45-days old L. esculentum plants under PPN infection. Data is presented as means of three replicates \pm SD and HSD values. F ratio values, ${ }^{*}$ indicates significance at $p \leq 0.05$ and ${ }^{* *}$ indicates significance at $p \leq 0.01$ ). Different letters on the graphs indicate that mean values of treatments are significantly different at $p<0.5$ according to Tukey's multiple comparison test.

\begin{tabular}{|c|c|c|c|c|c|c|c|c|c|}
\hline Treatments & $\begin{array}{c}\text { SOD } \\
(\text { Mean } \pm \text { SD) }\end{array}$ & $\begin{array}{c}\text { POD } \\
(\text { Mean } \pm \text { SD) }\end{array}$ & $\begin{array}{c}\text { CAT } \\
(\text { Mean } \pm \text { SD })\end{array}$ & $\begin{array}{c}\text { GPOX } \\
(\text { Mean } \pm \text { SD) }\end{array}$ & $\begin{array}{c}\text { APOX } \\
(\text { Mean } \pm \text { SD) }\end{array}$ & $\begin{array}{c}\text { DHAR } \\
(\text { Mean } \pm \text { SD) }\end{array}$ & $\begin{array}{c}\text { GST } \\
(\text { Mean } \pm \text { SD) }\end{array}$ & $\begin{array}{c}\text { GR } \\
(\text { Mean } \pm \text { SD) }\end{array}$ & $\begin{array}{c}\text { PPO } \\
(\text { Mean } \pm \text { SD) }\end{array}$ \\
\hline Control & $53.44 \pm 3.506^{\mathrm{d}}$ & $256.4 \pm 6.612^{f}$ & $54.08 \pm 1.859^{\mathrm{d}}$ & $23.58 \pm 0.8076^{\mathrm{e}}$ & $389.1 \pm 9.030^{\mathrm{d}}$ & $136.8 \pm 1.718^{\mathrm{d}}$ & $21.73 \pm 1.672^{\mathrm{e}}$ & $210.5 \pm 5.574^{\mathrm{e}}$ & $71.13 \pm 2.373^{f}$ \\
\hline $\mathrm{N}$ & $71.97 \pm 1.254^{\mathrm{b}}$ & $402.8 \pm 1.859^{c}$ & $70.94 \pm 0.941^{\mathrm{b}}$ & $33.65 \pm 1.1611^{\mathrm{c}}$ & $442.3 \pm 11.220^{\mathrm{c}}$ & $150.5 \pm 6.151^{c}$ & $27.45 \pm 1.831^{\mathrm{c}}$ & $353.9 \pm 3.156^{b}$ & $84.82 \pm 3.642^{\mathrm{e}}$ \\
\hline M1 & $61.0 \pm 1.787^{c}$ & $349.8 \pm 6.733^{e}$ & $58.77 \pm 3.792^{c, d}$ & $27.35 \pm 0.8783^{d}$ & $651.0 \pm 16.274^{a}$ & $167.1 \pm 3.257^{b}$ & $32.03 \pm 2.427^{c}$ & $286.7 \pm 9.087^{c}$ & $96.28 \pm 3.006^{\mathrm{d}}$ \\
\hline $\mathrm{M} 1+\mathrm{N}$ & $84.45 \pm 2.184^{\mathrm{a}}$ & $524.2 \pm 1.539^{a}$ & $78.62 \pm 2.826^{\mathrm{a}}$ & $36.0 \pm 0.7885^{b}$ & $510.9 \pm 3.854^{b}$ & $174.7 \pm 2.368^{\mathrm{a}, \mathrm{b}}$ & $38.04 \pm 1.908^{b}$ & $360.1 \pm 4.650^{\mathrm{a}, \mathrm{b}}$ & $137.7 \pm 4.165^{\mathrm{a}}$ \\
\hline M2 & $59.33 \pm 3.729^{c, d}$ & $370.3 \pm 1.270^{\mathrm{d}}$ & $63.14 \pm 2.310^{c}$ & $25.94 \pm 0.3994^{d}$ & $401.9 \pm 2.382^{d}$ & $156.7 \pm 3.503^{c}$ & $31.41 \pm 1.5008^{\mathrm{c}, \mathrm{d}}$ & $246.8 \pm 13.211^{\mathrm{d}}$ & $111.8 \pm 3.856^{\mathrm{c}}$ \\
\hline $\mathrm{M} 2+\mathrm{N}$ & $78.74 \pm 1.727 \mathrm{ab}$ & $454.6 \pm 6.143^{b}$ & $76.50 \pm 1.901 \mathrm{a}, \mathrm{b}$ & $40.1 \pm 0.9736^{\mathrm{a}}$ & $522.4 \pm 8.446^{\mathrm{b}}$ & $183.2 \pm 2.587^{\mathrm{a}}$ & $44.44 \pm 2.130^{\mathrm{a}}$ & $379.8 \pm 3.659^{\mathrm{a}}$ & $123.8 \pm 5.584^{b}$ \\
\hline F-ratio $_{(\mathrm{df} 1,12)} \mathrm{T}$ & $291.8^{* *}$ & $3667.7^{* *}$ & $193.4^{* *}$ & $720.3^{* *}$ & 3.199 & 90.11 ** & $81.78^{* *}$ & $11730.7^{* *}$ & $148.3^{* *}$ \\
\hline F-ratio $_{(\mathrm{df} 2,12)} \mathrm{D}$ & $23.85^{* *}$ & $849.5^{* *}$ & $18.97^{* *}$ & $40.77^{* *}$ & $246.7^{* *}$ & $113.34^{* *}$ & $78.78^{* *}$ & $54.79 * *$ & $204.4^{* *}$ \\
\hline F-ratio $_{(\mathrm{df} 2,12)} \mathrm{T} \times \mathrm{D}$ & 1.599 & $142.6^{* *}$ & $4.795^{* *}$ & $16.29^{* *}$ & $155.47^{* *}$ & $11.09^{* *}$ & $6.881 *$ & $37.20^{* *}$ & 26.91 ** \\
\hline HSD & 6.967 & 12.972 & 6.686 & 2.375 & 36.445 & 9.758 & 5.308 & 19.95 & 10.69 \\
\hline
\end{tabular}



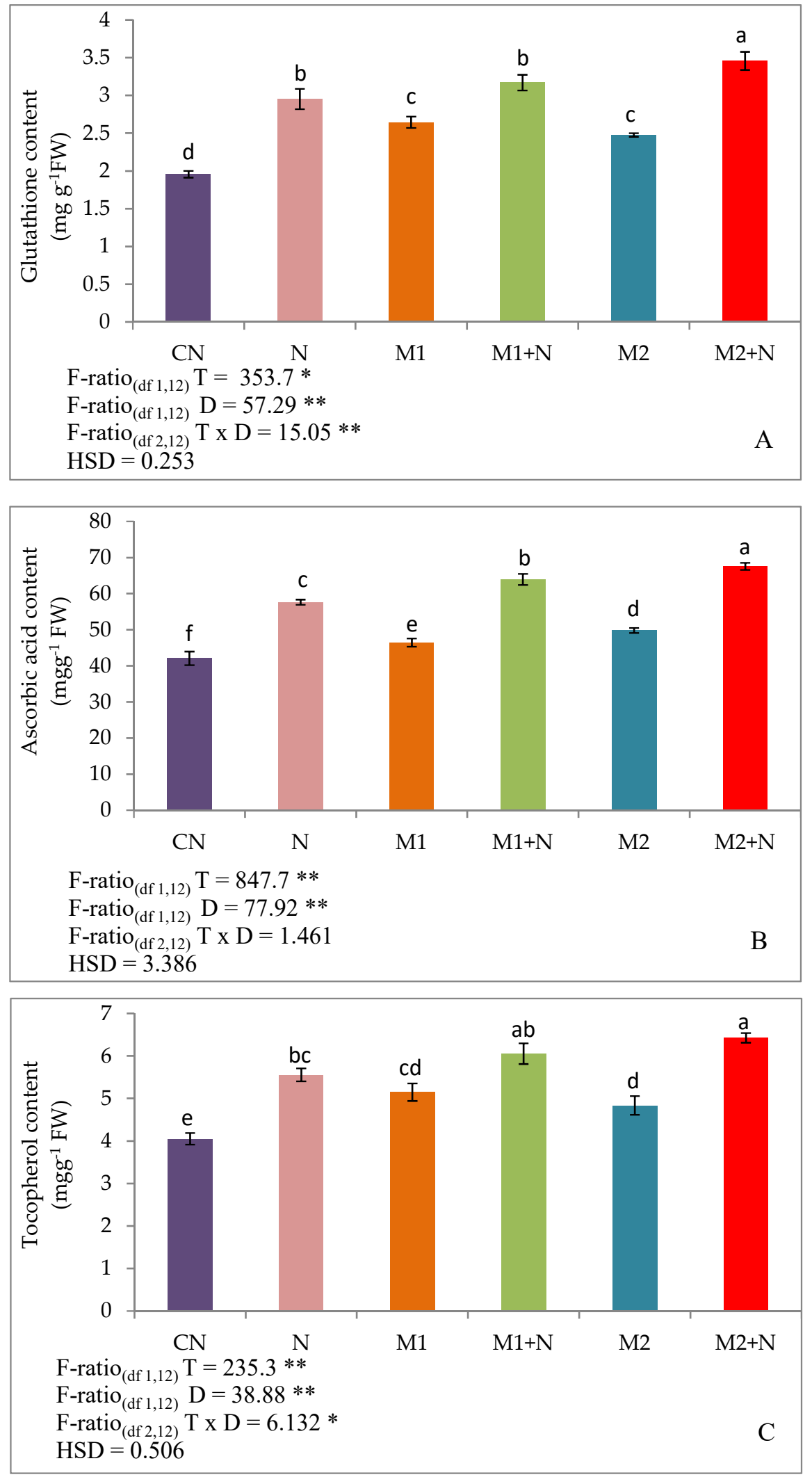

Figure 3. Effect of M1 ( $10^{9}$ cells/ ml $)$ and M2 (109 cells/ ml) on: (A) Glutathione content, (B) Ascorbic acid content and (C) Tocopherol content in 45-days old L. esculentum plants under PPN infection. Data is presented as means of three replicates \pm SD and HSD values. F ratio values, ${ }^{*}$ indicates significance at $p \leq 0.05$ and ${ }^{* *}$ indicates significance at $p \leq 0.01$ ). Different letters on the graphs indicate that mean values of treatments are significantly different at $p<0.5$ according to Tukey's multiple comparison test. 


\subsection{Phenolic Compounds}

Effect of Biocontrol Agents on Total Phenols, Flavonoids and Anthocyanins in PPN Infected L. esculentum Plants

The present study depicted that measurement of total phenols, flavonoid and anthocyanin levels were enhanced in the plants stressed with nematodes. The upliftment in the levels of total phenols occurred by $25.56 \%$, flavonoids by $20.93 \%$ and anthocyanins by $58.46 \%$, respectively. However, the further enhancement in the levels of these phenolic compounds were observed after the treatment of $P$. aeruginosa (M1) by $40.37 \%$ (total phenols), $40.46 \%$ (flavonoids) and $54.67 \%$ (anthocyanins) in infected plants. The inoculation of infected plants with B. gladioli (M2) also maximised the levels of total phenols, flavonoids and anthocyanins by $62.1,14$ and $75.51 \%$ in contrast to experimental controls respectively (Figure 4).
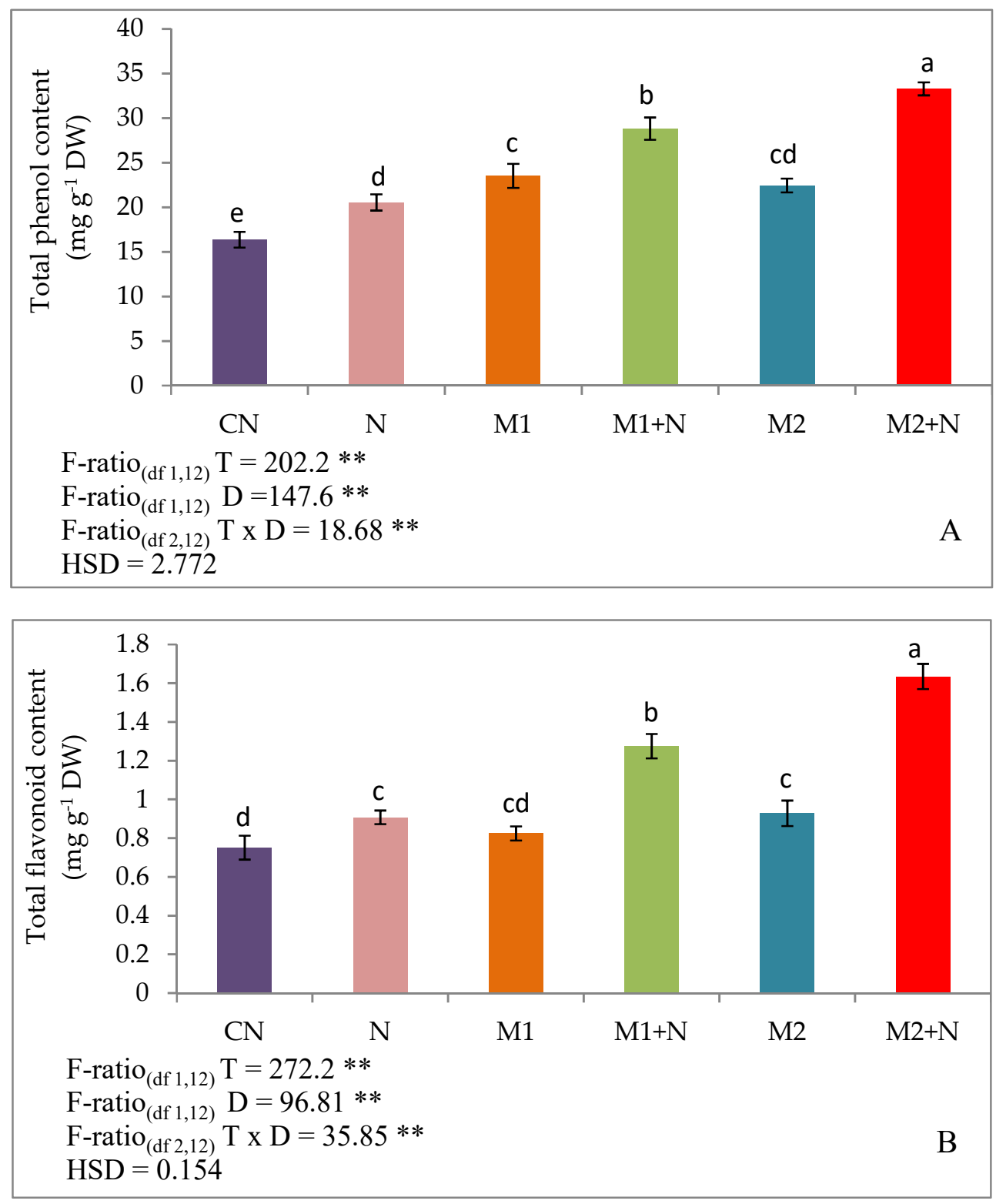

Figure 4. Cont. 


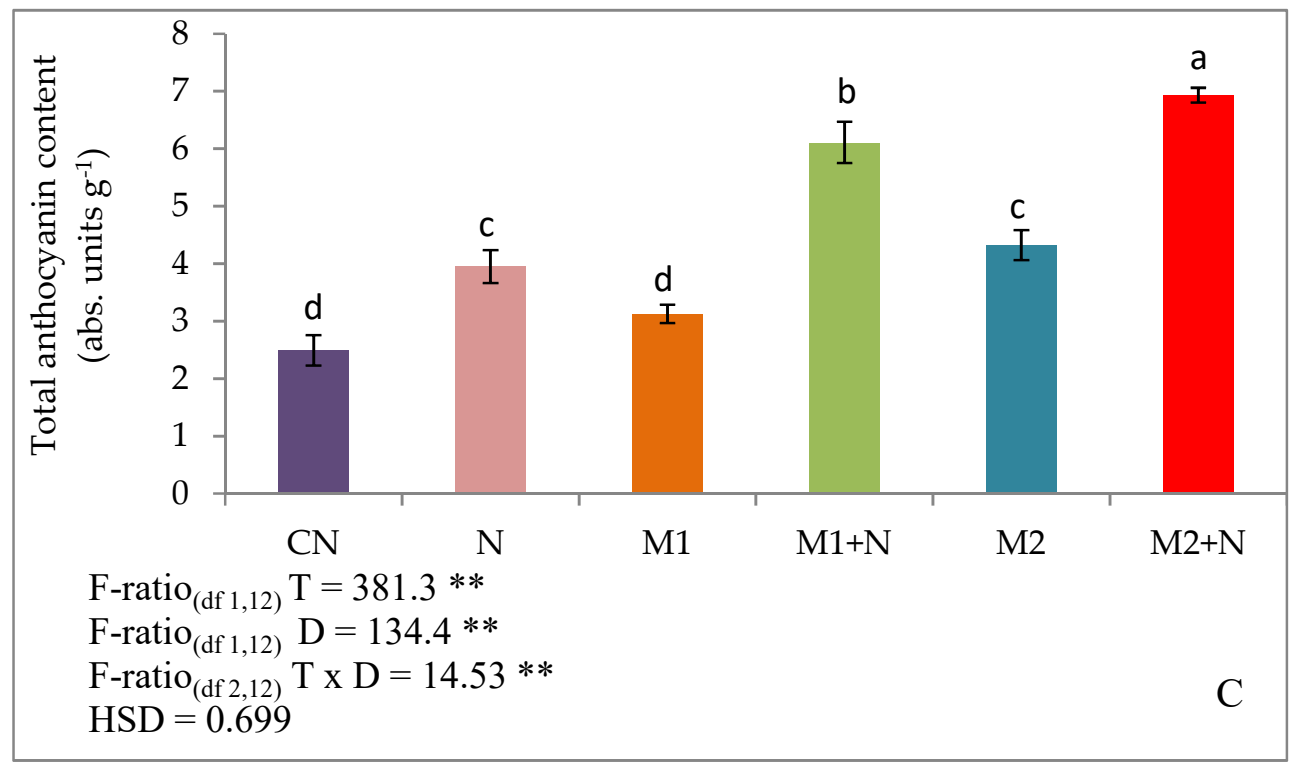

Figure 4. Effect of M1 (109 cells/mL) and M2 (109 cells $/ \mathrm{mL})$ on Phenolic compounds (A) Total Phenols (B) Total Flavonoids (C) Total Anthocyanins in 45-days old L. esculentum under PPN infection. Data is presented as means of three replicates \pm SD and HSD values. F ratio values, ${ }^{*}$ indicates significance at $p \leq 0.05$ and ${ }^{* *}$ indicates significance at $p \leq 0.01$ ). Different letters on the table indicate that mean values of treatments are significantly different at $p<0.5$ according to Tukey's multiple comparison test.

\subsection{Osmoprotectants}

3.8.1. Effect of Biocontrol Agents on Total Osmolytes, Carbohydrates, Reducing Sugars in PPN Infected L. esculentum Plants

The levels of total osmolytes, carbohydrates and reducing sugars were uplifted by $8.38,14.1$ and $23.09 \%$ respectively, in PPN stressed plants in comparison to experimental control plants. Increase in the total osmolytes was recorded by 25.97 and $33.26 \%$ in stressed plants after treating with P. aeruginosa (M1) and B. gladioli (M2) respectively. Besides, the total carbohydrates were also raised by 23.26 and $35.21 \%$ in infected plants in the presence of P. aeruginosa (M1) and B. gladioli (M2) respectively. The reducing sugar content was also improved by $27.7 \%$ after the amendment with $P$. aeruginosa (M1) and $40.87 \%$ with B. gladioli (M2) treatment (Figure 5).

3.8.2. Effect of Biocontrol Agents on Trehalose, Glycine Betaine, Proline and Free Amino Acid in PPN Infected L. esculentum Plants

The PPN infection in L. esculentum plants also escalated trehalose, glycine betaine and proline content by $12.06,16.23$ and $34.85 \%$ respectively, in comparison to experimental controls. The free amino acid content however, decreased by $30.61 \%$ in PPN infected plants when compared to controls. The stimulation in trehalose, glycine betaine and proline levels was seen, subsequently after addition of $P$. aeruginosa (M1) by $61.64,30.61$ and $16.44 \%$ respectively. The improvement in trehalose, glycine betaine and proline levels were also recorded in the plants inoculated with B. gladioli (M2) by 42.18, 55.93 and $35.71 \%$ respectively. Elevation in the free amino acids by 69.12 and $78.04 \%$ was noticed in PPN infested plants when inoculating agents P. aeruginosa (M1) and B. gladioli (M2) were added (Figure 5). 

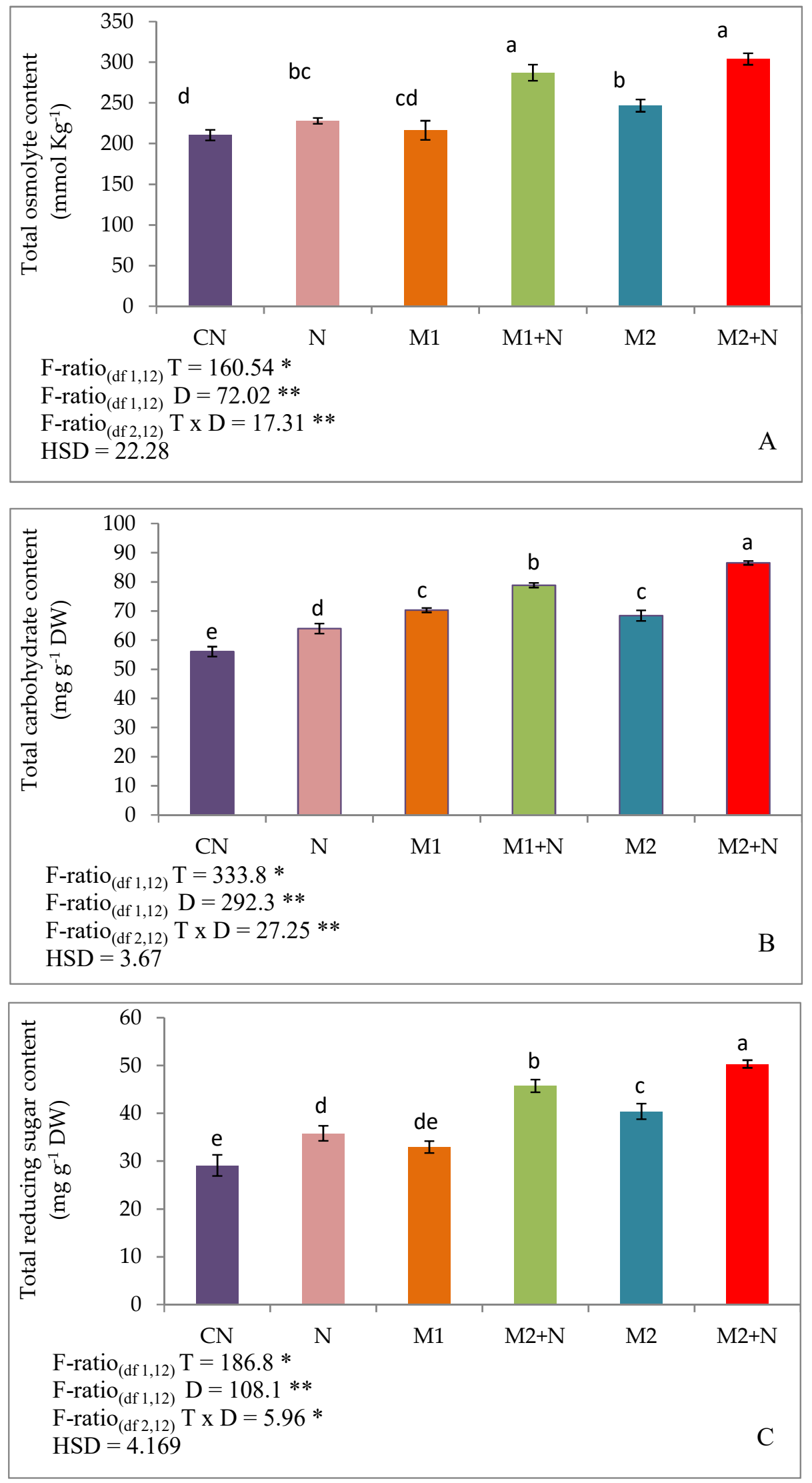

Figure 5. Cont. 

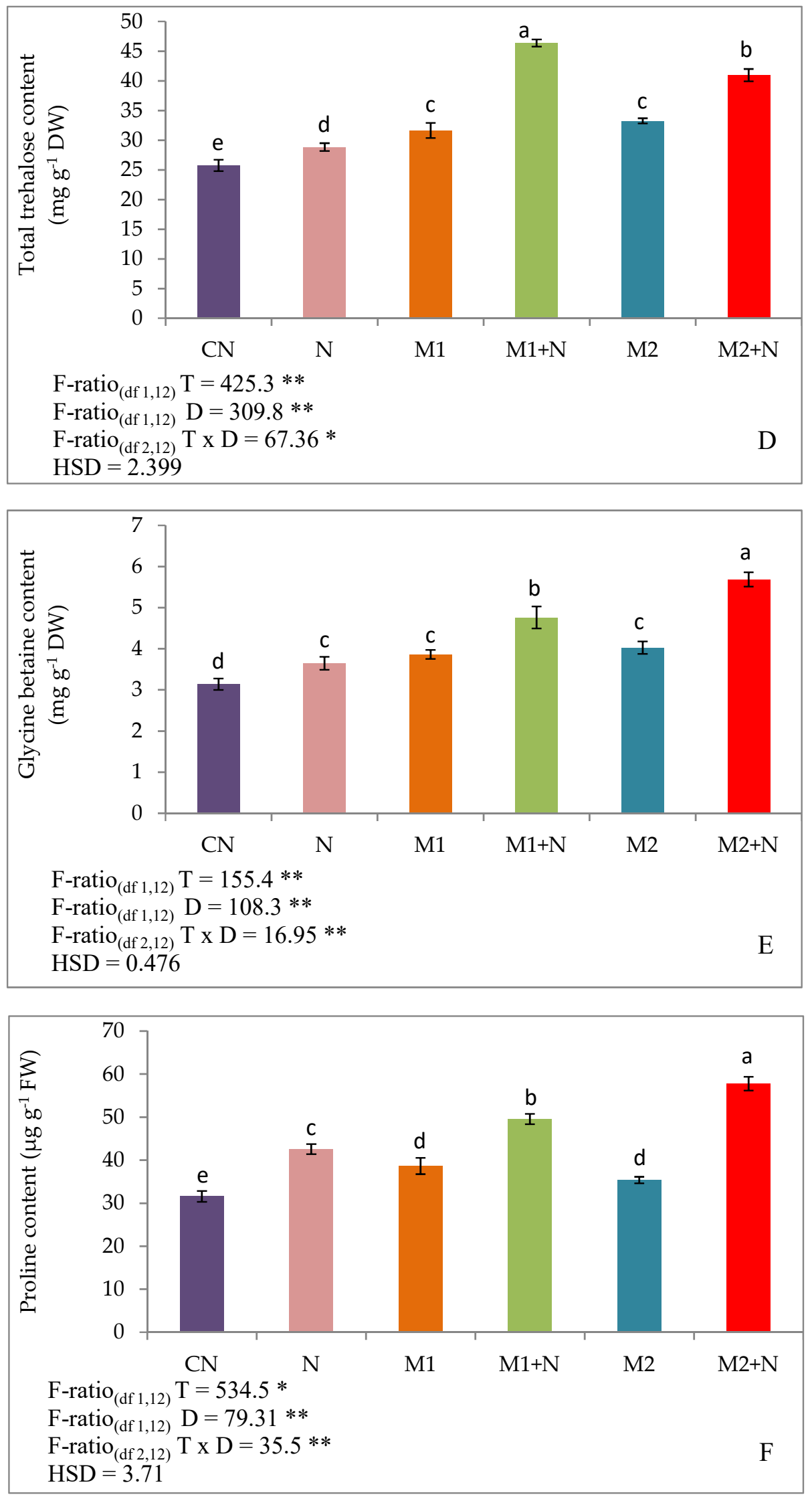

Figure 5. Cont. 


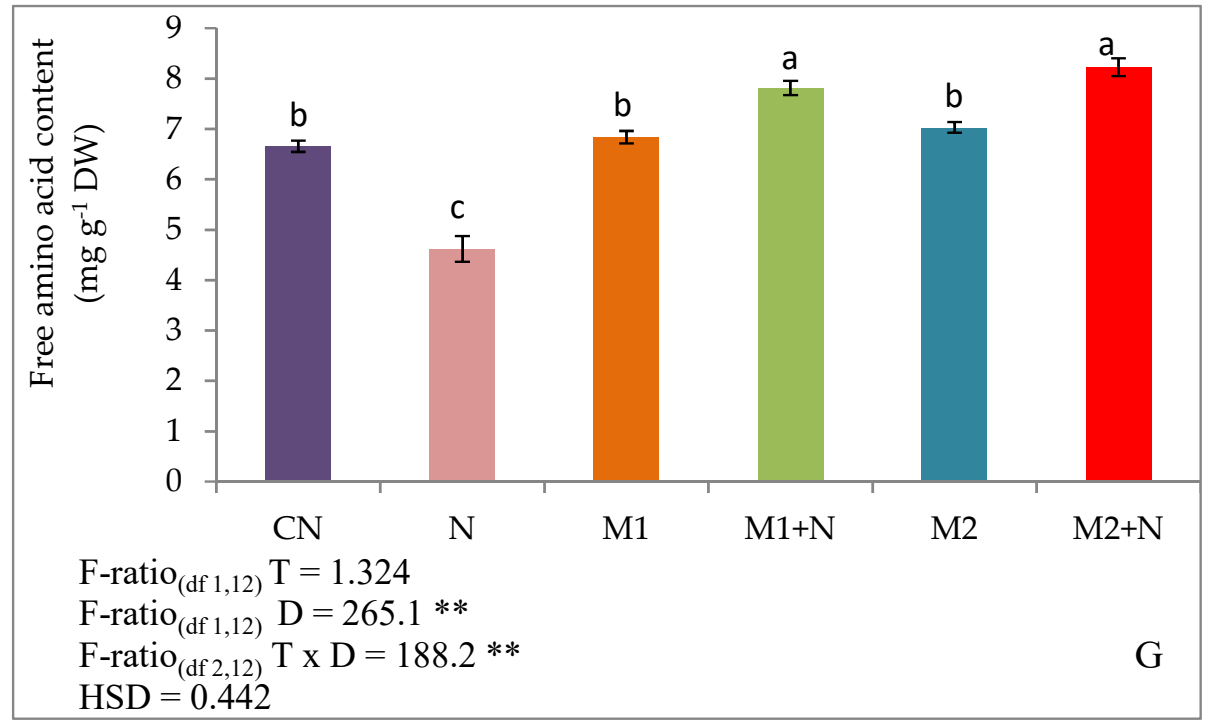

Figure 5. Effect of M1 ( $10^{9}$ cells $\left./ \mathrm{mL}\right)$ and $\mathrm{M} 2\left(10^{9}\right.$ cells $\left./ \mathrm{mL}\right)$ on different Osmoprotectants (A) Total osmolytes (B) Total carbohydrates, (C) Total reducing sugars (D) Trehalose content (E) Glycine betaine content (F) Proline content (G) Free amino acid content in 45-days old L. esculentum under PPN infection. Data is presented as means of three replicates \pm SD and HSD values. F ratio values, ${ }^{*}$ indicates significance at $p \leq 0.05$ and ${ }^{* *}$ indicates significance at $p \leq 0.01$ ). Different letters on the table indicate that mean values of treatments are significantly different at $p<0.5$ according to Tukey's multiple comparison test.

\subsubsection{Effect of biocontrol Agents on Organic Acid Profiling in PPN Infected L. esculentum Plants}

Organic acid profiling was done to assess the levels of fumaric acid, succinic acid, citric acid and malic acid in plants exposed to nematode infestation. An upregulation in the levels of organic acids, fumaric acid $(9.7 \%)$, succinic acid $(29.67 \%)$, citric acid (42.26\%) and malic acid (57.52\%) was noticed in PPN exposed plants in contrast to experimental controls. The drastic elevation in fumaric, succinic, citric and malic acid was recorded by $27.07,12.02,43.9$ and $118.8 \%$ respectively, after the PPN infected plants were amended with P. aeruginosa (M1). Similarly, organic acid levels of infected plants inoculated with B. gladioli (M2) were also enhanced by $38.05 \%$ (fumaric acid), by $7.16 \%$ (succinic acid), by $62.66 \%$ (citric acid) and by $140.56 \%$ (malic acid) respectively (Table 4).

Table 4. Effect of M1 ( $10^{9}$ cells $\left./ \mathrm{mL}\right)$ and M2 $\left(10^{9}\right.$ cells $\left./ \mathrm{mL}\right)$ and their combinations on organic acid contents (Fumaric acid, Citric acid, Succinic acid, Malic acid) in 45-days old L. esculentum plants under PPN infection.

\begin{tabular}{|c|c|c|c|c|}
\hline Treatments & $\begin{array}{c}\text { Fumaric Acid } \\
\left(\mathrm{mg} \mathrm{g}^{-1} \text { FW) }\right. \\
(\text { Mean } \pm \text { SD) }\end{array}$ & $\begin{array}{c}\text { Citric Acid } \\
\left(\mathrm{mg} \mathrm{g}^{-1} \mathrm{FW}\right) \\
(\text { Mean } \pm \text { SD) }\end{array}$ & $\begin{array}{c}\text { Succinic Acid } \\
\left(\mathrm{mg} \mathrm{g}^{-1} \text { FW) }\right. \\
(\text { Mean } \pm \text { SD })\end{array}$ & $\begin{array}{c}\text { Malic Acid } \\
\left(\mathrm{mg} \mathrm{g}^{-1} \mathrm{FW}\right) \\
(\text { Mean } \pm \text { SD) }\end{array}$ \\
\hline $\mathrm{CN}$ & $0.515 \pm 0.0060^{\mathrm{e}}$ & $4.337 \pm 0.1838^{\mathrm{e}}$ & $0.930 \pm 0.0225^{c}$ & $3.409 \pm 0.1758^{f}$ \\
\hline $\mathrm{N}$ & $0.565 \pm 0.0111^{d}$ & $6.162 \pm 0.1476^{\mathrm{cd}}$ & $1.206 \pm 0.0338^{b}$ & $5.379 \pm 0.2266^{\mathrm{e}}$ \\
\hline M1 & $0.649 \pm 0.0225^{c}$ & $5.674 \pm 0.1402^{d}$ & $0.985 \pm 0.0121^{c}$ & $6.403 \pm 0.1581^{d}$ \\
\hline $\mathrm{M} 1+\mathrm{N}$ & $0.718 \pm 0.0193^{b}$ & $8.878 \pm 0.2081^{b}$ & $1.351 \pm 0.0327^{\mathrm{a}}$ & $11.778 \pm 0.4950^{b}$ \\
\hline M2 & $0.611 \pm 0.0106^{\mathrm{c}}$ & $6.544 \pm 0.1093^{c}$ & $0.953 \pm 0.0106^{\mathrm{c}}$ & $9.237 \pm 0.1091^{\mathrm{c}}$ \\
\hline $\mathrm{M} 2+\mathrm{N}$ & $0.780 \pm 0.0198^{a}$ & $10.020 \pm 0.3984^{a}$ & $1.413 \pm 0.0353^{\mathrm{a}}$ & $12.94 \pm 0.3555^{\mathrm{a}}$ \\
\hline F-ratio $_{(\mathrm{df} 1,12)} \mathrm{T}$ & $160.7^{* *}$ & $750.6^{* *}$ & $859.22 * *$ & $746.3^{* *}$ \\
\hline F-ratio $_{(\mathrm{df} 2,12)} \mathrm{D}$ & $173.2^{* *}$ & $297.2^{* *}$ & $33.144^{* *}$ & $866.5^{* *}$ \\
\hline F-ratio $_{(\mathrm{df} 2,12)} \mathrm{T} \times \mathrm{D}$ & $23.83^{* *}$ & $24.24^{* *}$ & $17.907^{* *}$ & $53.17^{* *}$ \\
\hline HSD & 0.0440 & 0.6022 & 0.0729 & 0.7842 \\
\hline
\end{tabular}

Data is presented as means of three replicates \pm SD and HSD values. F ratio values, ${ }^{*}$ indicates significance at $p \leq 0.05$ and $^{* *}$ indicates significance at $p \leq 0.01$ ). Different letters on the table indicate that mean values of treatments are significantly different at $p<0.5$ according to Tukey's multiple comparison test. 


\section{Discussion}

Microbial community present in the rhizosphere have been explored to be useful as natural biocontrol agents in managing PPN infection in L. esculentum and improving their growth conditions under normal as well as infectious stages [32]. Our studies indicated that PPN infection declined the growth of 45-days old infected plants in terms of root length, shoot length, plant biomass (fresh and dry weight) and induced gall formation in plants. Earlier also, reduction in the growth attributes have been reported by Gupta et al. [62], Bacopa monnieri plants raised under the influence of nematodes. Moreover, reduction in growth of Salvado rapersica L. and S. oleoides Decne was also reported in terms of decreased plant height, root length, root and shoot biomass, due to PPN infection in the plant species [28]. The reduction in the growth parameters of plants occurs due to infestation of PPN into the roots followed by their further proliferation into interior region leading to development of galls over the root surfaces [63]. Furthermore, the development of galls in root zone of infected plants have also been recorded in the present study. Similar to our observation, the formation of galls have also been noticed in tomatoes and carrots due to the infection of M. incognita [19]. They illustrated that nematodes are quite effective in penetrating the root system both fibrous and tap root through secretion of array of compounds to dissolute cell wall for invasion [19]. The present study also depicted that inoculation of P. aeruginosa(M1) and B. gladioli (M2) improved the morphological characters of the plants inhabited with PPNs. Our studies are in the agreement to previous studies conducted by Abd-El-Khair et al. [64], who reported that biocontrol agents Bacillus subtilis, B. pumilus and P. fluorescens had a protective role against PPN M. incognita in improving root length, shoot length, fresh and dry weights in cowpea. According to their assumptions, the biocontrol agents have the stimulating effects on plants by inducing growth, plant nutrition, producing plant hormones and suppressing various pathogens in the surrounding zones [64]. Moreover, they can also survive under severe conditions to act aggressively against PPNs by producing growth promoting materials in order to cease the negative effects of pathogens [65]. The reduction in the gall number, egg masses and gall index have also been reported by Viljoen et al. [19] in tomato and carrot plants infected with PPNs on supplementation of B. firmus, B. aryabhattai, B. cereus, Paenibacillus baricinonensis and P. alvei respectively. They concluded that the reduction in the gall formation in the plant species is mainly because of antagonistic effects of these microbial strains on PPNs each possessing its own mode of action to inhibit their proliferation around the root zones [19]. It was also reported that Bacillus and Paenibacillus sp. are involved in the production of different nematicidal substances that directly inhibit the growth activities of PPNs [66]. Similarly, plant growth promotion has also been studied in nematode infected cucumber plants after the supplementation of Photorhabdus luminescens in terms of leaf number, root and shoot length, plant biomass, and fruit yield [67]. The improvement in the growth parameters and reduction in the gall formation of plants in current study might be due to production of extracellular enzymes (serine alkaline protease, chitinases, glucanases etc.), antibiotics and toxins to induce mortality of nematodes $[19,32,67]$. The main mechanism associated with escalated resistance is the colonisation of the plant species to mediate systemic resistance against parasitic nematodes. This tends to barricade the biting of nematodes to plant roots thereby, inhibiting their penetration inside roots to the maximum extent.

The results of the present study also demonstrated the reduction in the plant pigments in plants infected with nematodes. Our results concur with many similar findings, as it is extensively reported that Meloidogyne sp. reduced chlorophyll pigment in tomato plants [68]. They found that disruption in the plant pigments occur mainly due to hindrance in the reactions associated with photosynthesis due to nematode infection, that caused the loss of plant pigments derived during photosynthetic processes [68]. Moreover, nematode damage the root and leaf tissues, chloroplasts and disturb the translocation of photosynthates in plants [69]. The studies conducted in Capsicum annuum L. showed a significant reduction in the total carotenoid levels after the inoculation of M. incognita [70]. Our results also demonstrated an elevation in the levels of plant pigments in nematode infected L. esculentum plants after the rhizobacterial treatment. Our findings coincide with the studies reported by Abd-El-Khair et 
al. [64], who found the raised levels of chla, chlb, total chlorophyll and carotenoid content in nematode infested cowpea plants. Furthermore, a study reported in nematode infected Pinus pinaster revealed a decreased incidence of nematode proliferation after microbial treatment along with the prevention in the degradation of plant photosynthetic pigments. They found a significant stimulation in the pigment content in infected plants due to protection of key enzymes involved in photosynthesis from nematode attack [71]. The improved plant pigment levels in the present study are most likely due to protection of photosynthetic apparatus by microbes along with their role in improving translocation of nutrients in plants that ultimately regulates the effective photosynthesis. Moreover, the mechanism entails microbe mediated limitation of PPN migration inside the vascular tissues that ramifies in effective transport of essential minerals required for photosynthesis.

A down regulation in the activities of gas exchange parameters have also been noted in nematode infested plants in the present work. Our studies corroborate with the findings of Goulart, et al. [70], who suggested that nematode infected coffee plants showed remarkable reduction in the transpiration rate, stomatal conductance and $\mathrm{CO}_{2}$ concentration. Moreover, they found that overall rate of photosynthesis was lowered in infected plants with reduced starch synthesis [72]. Similarly, the reduction in gaseous exchange parameters, mainly transpiration and assimilation rate in nematode infected Solanum tuberosum plants was also recorded [73]. The decrease in the gaseous exchange mechanisms in plants under nematode infection are mainly due to the impairment in the water transport pathways because of root damage by nematodes [74]. Moreover, the reduction in the net photosynthesis accompanied by stomatal regulation and photochemical efficiency was observed in C. annuum under the infection of root-feeding parasitic nematodes [70]. The increase in the gaseous exchange parameters was noticed in the present study when an inoculation of P. aeruginosa and B. gladioli was done. The results of present study coincide with the earlier studies conducted by Mioranza et al. [75] in tomato plants infested by M. incognita that showed an elevation in photosynthetic rate, stomatal conductance, internal $\mathrm{CO}_{2}$ concentration, leaf temperature and transpiration upon supplementation of Thuya occidentalis to infected plants. Furthermore, it was revealed that $M$. incognita infected tomato plants led to enhanced effects upon stomatal conductance and transpiration rate in the presence of $B$. lichenoformis [76]. The acceleration of gaseous exchange parameters in the current study is most likely due to higher synthesis of enzymes involved in photosynthetic processes.

The current study also reported that nematode infection uplifted the levels of oxidative stress markers in plants. Our studies find support from our earlier studies, Khanna et al. [32], where levels of superoxide anions, $\mathrm{H}_{2} \mathrm{O}_{2}$ and MDA were found raised in 10-days old seedlings of tomato under the influence of PPNs. This is directly linked to oxidative damage in plants due to pathogenicity of parasitic nematodes in the form of ROS (reactive oxygen species) generation. Moreover, studies have been reported where levels of total reactive oxygen species, superoxide anions, $\mathrm{H}_{2} \mathrm{O}_{2}$ and PCD (programmed cell death) were elevated in B. monnieri L. infected with PPNs [77]. The accumulation of oxidative stress markers and free radicals occurs as a result of toxic by-products of metabolic pathways in plants, when their levels exceed the optimum limits on exposure to parasitic nematodes [78]. Our studies also showed a significant reduction in the levels of all the stress markers in the presence of biocontrol agents. Similar to our studies, the pathogen induced overproduction of ROS has been reported to damage lipid synthesis and biomolecules, that has been considerably alleviated in the presence of microbial agents, implying their role as true antagonists against PPNs [79]. However, the reduction in the levels of MDA have also been observed in Cicerarietinum plants, prominently after their treatment with microbial consortium [80]. Another study revealed that nematode infested B. monnieri L. plants when inoculated with biocontrol agents (Chitinphilus sp. and Streptomyces sp.) lowered lipid peroxidation, superoxide anions and hydrogen peroxide levels [77]. They speculated that these inoculating agents had a stimulatory effect in defense mechanisms through reducing the free radicals generated and strengthening their immune system. In addition, they also strengthen the cell membrane of plant tissues that prevent their negative effects on biomolecules and also in preventing their movement towards other parts of the plant [81]. The mechanism associated with the reduced 
levels of oxidative stress markers in the present study by the aid of microbes is most likely due to elevation in the chain of resistance processes and antioxidative defense genes in plants along with their abilities to directly scavenge the ROS initiated during stress. Along with this, they also restricts their invasion inside the plants so as to balance the redox homeostasis with the plant inner zone.

The up regulation in the activities of enzymatic as well as non-enzymatic antioxidants have also been observed in the present study in plants associated with nematode infection. A study reported in barley infected with PPNs showed enhanced activities of SOD, POD, CAT and PPO [82]. They reported that increase in antioxidative enzymes are relative to resistance mechanisms developed by plants. Moreover, enhanced activities of peroxidases (APOX, GPOX and POD) are directly linked to their involvement in providing structural rigidity to plant tissues through enhanced lignin synthesis in cell walls in order to prevent the nematode penetration in plants [83]. Increases in the activities of peroxidases have also been reported in Ipomoea batatas subjected to PPN infection as assessed through transcriptomic analysis [84]. Moreover, an elevation in GPOX, CAT and SOD activities was observed in tomato plants infected by M. incognita [85]. The increase in the activities of GR, GST and other antioxidants in plants exposed to nematode infection are due to higher glutathione pools that further activates the enzymes DHAR and GPOX, key enzymes of GR cycle. Also, the level of non-enzymatic antioxidants glutathione, ascorbic acid and tocopherol were enhanced in nematode affected plants in the present study. AsA-GSH pathway is the most important pathway that gets activated during nematode infection in plants. It has been reported to activate the antioxidants as a defense strategy in plants followed by maintaining the redox state during plant-nematode interactions [86]. These antioxidants have been known to directly participate in free radical scavenging, against ROS accumulated during nematode attack [86]. Additionally, tocopherol have been seen to scavenge lipid peroxy radicals accumulated within cell membrane via free radical reactions [87]. Accumulation of different antioxidants have been reported in grape vine by Kesba and El-Beltagi [88] during nematode infection. Our results also showed further upliftment of enzymatic and non-enzymatic antioxidants following treatment with rhizobacterial strains. Our findings corroborate with the studies conducted by Molinari and Leonetti [89], who reported modulation in the activities of defense genes encoding antioxidative system $C A T, A P O X$ in nematode infected tomato plants. They also reported that SAR (Systemic Acquired Resistance) is the proposed mechanism that activates molecular signaling at different stages of nematode infection within plants, thereby preventing their penetration and movement inside roots [89]. Furthermore, another study reported in tomato plants infected with PPNs showed higher activities of SOD and POD after the inoculation of Drechslerella dactyloides and Dactylaria brochopaga [90]. According to their research, the microbes participate in the defense signaling during the presence of pathogens, that tend to up regulate the activities of specific biomolecules and antioxidants [90]. Moreover, SOD being a first line of defense in dismutating $\mathrm{H}_{2} \mathrm{O}_{2}$ into non-toxic forms is foremost activated by microbes against ROS generated in cytosol during respiration and photosynthesis [91]. Elevation in the SOD activity and ascorbic acid content have also been reported in nematode infested B. monnieri L. plants under the influence of Chitophilus sp. and Streptomyces sp. [62,77]. Also, the synthesis of non-enzymatic antioxidants were enhanced in these plants. The mechanism associated with stimulatory effects of microbes on antioxidative defense system is most probably due to up-regulation of genes and protein transcripts of antioxidant molecules. And this further attributes to the adaptive responses of plants with protection from PPN infection. The microbes have the capacity to incline the immune responses in plants against toxic environment created within them by advent of PPN proliferation.

Present results also demonstrated the accumulation of phenolic compounds in nematode infested plants. The increased levels of total phenolics have also been reported by Gálvez et al. [70] in C. annuum after PPN inoculation in order to induce the resistance in plants. Furthermore, a study conducted in Oryza sativa associated with PPN showed higher levels of total phenols (TP) in plants. They depicted that TP induced lignification in epidermal regions of plants, as a constitutive and inducible post penetration mechanism for providing resistance against nematode infection [92]. Flavonoids also act as 
signaling molecules during plant defense towards PPNs in rhizosphere in modulating auxin transport during gall formation. A study depicting role in flavonoids in nematode parasitized Medicago truncatula was conducted, that revealed an induction in the flavonoid pathways to accumulate different flavonoids such as chalcones and flavonones (kaempferol, flavone, isoflavonoids, medicarpin, pterocarpans etc.) to protect them against PPNs and inhibiting gall development in plants [93]. An increase in the levels of anthocyanins was also observed by Labudda et al. [94], in Arabidopsis thaliana infected with nematodes as an important antioxidant in protecting the plants from infection. Our study showed a further enhancement in the levels of phenolic compounds when rhizobacterial inoculations were done in PPN infected plants. It was revealed by Nunes da Silva et al. [71] in nematode stressed P. pinaster that biosynthesis of phenolics was dramatically increased with the reduction of nematode population at that specific site, being a crucial metabolite in controlling the pathogen prevalence. This is mainly attributed to activation of shikimate biosynthetic pathway by microbes to overproduce metabolites involved in the resistance mechanisms [71]. It was further suggested that inoculation of D. dactyloides and D. brochopaga in nematode infected tomato plants led to accumulation of phenolic compounds and enzymes involved in its synthesis [90]. They reported that PGPR activated PAL (Phenylalanine ammonia lyase) pathway in roots to improve plant growth, trap nematode population and initiate ISR in plants. Increase in the total phenolic content was also recorded in nematode infected cowpea plants under the influence of different rhizobacterial strains such as B. subtilis, P. fluorescens and B. pumilus respectively [64]. This phenomenon is quintessential to eradicate the impact of infection from the plants. It can be relatable to direct involvement of phenolic compounds in preventing the impregnation of nematodes inside plant tissues. The phenol deposition at cell walls makes intricate for PPN to biting and invading further inside plants.

Secondary metabolites also known as defense-related metabolites are activated in plants against pathogen attack. They play an important role in defense by triggering direct toxic effects on pathogen or by acting as signaling molecule to activate defense mechanisms in plants [95]. Present study showed a stimulation in the secondary metabolites (osmoprotectants and organic acids) in nematode infested plants. A remarkable increase in the total carbohydrates was observed in A. thaliana after the inoculation of PPN [94]. They speculated that an enhancement in the carbohydrates is due to alteration in the photosynthetic efficacy, in order to maintain the permanent inflow of sugars for nematodes prevailing in roots. The amino acid levels were also reported to be lessened in C. annuum plants infected with PPNs [70]. They formulated that Leu, Gly, Phe, Cys, Gly, Thr, Val and Ala were found to be declined in infected plants due to the alterations in the expression levels of different genes involved in amino acid metabolism [70]. Moreover, a study conducted in A. thaliana roots also showed a higher accumulation of different sugars such as raffinoses, trehaloses, ketoses and kestoses and amino acids (methionine, glutamine, aspartic acid, glutamic acid) in nematode infected plants [96]. According to their analysis, the higher levels of these metabolites produced under nematode infection are mainly due to the fact that they interfere with nematode-plant signaling by reducing the incidence of nematode associations with plants [96]. An elevation in organic acid levels has also been observed in nematode infested C. annuum plants [97]. The higher levels of organic acid synthesis in plants have been linked to disease resistance against different pathogens [98]. Our results also demonstrated a further rise in the secondary metabolic profiles in nematode infested plants after amendment with PGPR. Studies have been reported that showed a modulation in the genes involved in amino acid metabolism in nematode infested $A$. thaliana plants inoculated with Serratia plymuthica M24T3 [99]. Furthermore, stimulation in the activities of secondary metabolic profiles have also been reported by Oh et al. [100] by Enterobacter arsburiae HK169 in nematode infected tomato plants in order to encounter the oxidative stress generated by pathogen attack. However, an upliftment in the secondary metabolic profiles have also been found in tomatoes and carrots exposed to nematode infection after the inoculation of PGPR, B. firmus T11, B. aryabhattai AO8, B. cereus, P. alvei T30 and P. barcinonensis A10 respectively [19]. The accumulation of organic acids has also been reported by inoculation of Aspergillus niger and $A$. candidus in plants exposed to nematode infection to form an antagonistic associations with them [101]. The metabolomic 
study showed exaggerated levels of secondary metabolite profiles in plants with respect to infection alone as well as with microbes. The main mechanism behind these triggered levels are attributed to activation of genes encoding enzymes involved in synthesis of different secondary metabolites.

\section{Conclusions}

Present work suggested the synergistic role of PGPR in providing rhizosphere community resilience under PPN stress. The association of microbes with plants in promoting growth, metabolic activities and upregulation of defense system to improve plant health and management of PPNs infestation has been explored. The use of microbes as biocontrol agents is the most recent and environment friendly strategy, as they improved the morphological, biochemical, physiological, and secondary metabolic profiles within plants. Moreover, they have also been known to induce ISR in plants along with the production of different toxins, antibiotics, enzymes etc. to control proliferation and penetration of nematodes within plants. They also alter the root exudations that further hinder the mobility of PPN into the soil so that they could not enter into the plant system. Consequently, it has been the most innovative approach to develop strategies for fabrication of most recent technologies in agricultural productivity in ecological manner. Nevertheless, further analysis is essential for better understanding of the mechanisms associated with plant-microbes-PPNs interactions affecting rhizospheric community, where the functions of rhizodeposition is primarily important.

Author Contributions: Conceptualization, P.O., R.B. and P.A.; methodology, K.K.; software, E.F.A. and A.H.; validation, K.K., A.S. and A.H.; formal analysis, K.K. and A.S.; investigation, K.K.; resources, P.O. and R.B.; data curation, P.O., E.F.A. and A.H.; writing—original draft preparation, K.K., and A.S.; writing-review and editing, P.O., R.B. and P.A.; visualization, P.O. and P.A.; supervision, R.B.; project administration, P.O. and R.B.; funding acquisition, E.F.A., A.H. and P.A.

Funding: The authors would like to extend their sincere appreciation to the Deanship of Scientific Research at King Saud University for funding this research group No (RGP-271).

Conflicts of Interest: The authors declare no conflict of interest.

\section{References}

1. Sudhakar, P.; Purushotham, K. Evaluation of F1 hybrids of tomato (Solanum lycopersicum L.). J. Res. ANGRAU 2009, 37, 77-81.

2. Meena, O.P.; Bahadur, V.; Jagtap, A.; Saini, P. Genetic analysis of agronomic and biochemical variables among different tomato (Solanum lycopersicum L.) accessions. J. Appl. Nat. Sci. 2015, 7, 806-816. [CrossRef]

3. Afifah, E.N.; Murti, R.H.; Nuringtyas, T.R. Metabolomics Approach for The Analysis of Resistance of Four Tomato Genotypes (Solanum lycopersicum L.) to Root-Knot Nematodes (Meloidogyne incognita). Open Life Sci. 2019, 14, 141-149. [CrossRef]

4. Coyne, D.L.; Cortada, L.; Dalzell, J.J.; Claudius-Cole, A.O.; Haukeland, S.; Luambano, N.; Talwana, H. Plant-Parasitic Nematodes and Food Security in Sub-Saharan Africa. Annu. Rev. Phytopathol. 2018, 56, 381-403. [CrossRef]

5. Somasekhar, N.; Prasad, J.S. Plant-Nematode Interactions: Consequences of Climate Change. In Crop Stress and Its Management: Perspectives and Strategies; Springer: Cham, The Netherlands, 2011; pp. 547-564. [CrossRef]

6. Sikora, R.A.; Coyne, D.; Hallmann, J.; Timper, P. Plant Parasitic Nematodes in Subtropical and Tropical Agriculture; Cabi: Beijing, China, 2018.

7. Ibrahim, H.M.M.; Ahmad, E.M.; Martínez-Medina, A.; Aly, M.A.M. Effective approaches to study the plant-root knot nematode interaction. Plant Physiol. Biochem. 2019, 141, 332-342. [CrossRef] [PubMed]

8. Davis, E. Getting to the roots of parasitism by nematodes. Trends Parasitol. 2004, 20, 134-141. [CrossRef] [PubMed]

9. Singh, R.; Phulera, S. Plant Parasitic Nematodes: The Hidden Enemies of Farmers; Excel India Publishers: New Delhi, India, 2015; Volume 68.

10. Quentin, M.; Abad, P.; Favery, B. Plant parasitic nematode effectors target host defense and nuclear functions to establish feeding cells. Front. Plant Sci. 2013, 4. [CrossRef] [PubMed] 
11. Eves-vandenAkker, S.; Birch, P.R.J. Opening the Effector Protein Toolbox for Plant-Parasitic Cyst Nematode Interactions. Mol. Plant 2016, 9, 1451-1453. [CrossRef]

12. Jacquet, M.; Bongiovanni, M.; Martinez, M.; Verschave, P.; Wajnberg, E.; Castagnone-Sereno, P. Variation in resistance to the root-knot nematode Meloidogyne incognita in tomato genotypes bearing the Mi gene. Plant Pathol. 2005, 54, 93-99. [CrossRef]

13. Golinowski, W.; Grundler, F.M.W.; Sobczak, M. Changes in the structure of Arabidopsis thaliana during female development of the plant-parasitic nematode Heterodera schachtii. Protoplasma 1996, 194, 103-116. [CrossRef]

14. Kyndt, T.; Vieira, P.; Gheysen, G.; de Almeida-Engler, J. Nematode feeding sites: Unique organs in plant roots. Planta 2013, 238, 807-818. [CrossRef] [PubMed]

15. Haydock, P.P.J.; Woods, S.R.; Grove, I.G.; Hare, M.C. Chemical control of nematodes. In Plant Nematology; CABI: Wallingford, UK, 2013; pp. 459-479. [CrossRef]

16. Compant, S.; Clément, C.; Sessitsch, A. Plant growth-promoting bacteria in the rhizo- and endosphere of plants: Their role, colonization, mechanisms involved and prospects for utilization. Soil Biol. Biochem. 2010, 42, 669-678. [CrossRef]

17. Collange, B.; Navarrete, M.; Peyre, G.; Mateille, T.; Tchamitchian, M. Root-knot nematode (Meloidogyne) management in vegetable crop production: The challenge of an agronomic system analysis. Crop Prot. 2011, 30, 1251-1262. [CrossRef]

18. Paul, D.; Lade, H. Plant-growth-promoting rhizobacteria to improve crop growth in saline soils: A review. Agron. Sustain. Dev. 2014, 34, 737-752. [CrossRef]

19. Viljoen, J.J.F.; Labuschagne, N.; Fourie, H.; Sikora, R.A. Biological control of the root-knot nematode Meloidogyne incognita on tomatoes and carrots by plant growth-promoting rhizobacteria. Trop. Plant Pathol. 2019, 44, 284-291. [CrossRef]

20. Borah, B.; Ahmed, R.; Hussain, M.; Phukon, P.; Wann, S.B.; Sarmah, D.K.; Bhau, B.S. Suppression of root-knot disease in Pogostemoncablin caused by Meloidogyne incognita in a rhizobacteria mediated activation of phenylpropanoid pathway. Biol. Control 2018, 119, 43-50. [CrossRef]

21. Glick, B.R. Bacteria with ACC deaminase can promote plant growth and help to feed the world. Microbiol. Res. 2014, 169, 30-39. [CrossRef]

22. Cetintas, R.; Kusek, M.; Fateh, S.A. Effect of some plant growth-promoting rhizobacteria strains on root-knot nematode, Meloidogyne incognita, on tomatoes. Egypt. J. Biol. Pest Control 2018, 28, 7. [CrossRef]

23. Li, X.; Hu, H.-J.; Li, J.-Y.; Wang, C.; Chen, S.-L.; Yan, S.-Z. Effects of the Endophytic Bacteria Bacillus cereus BCM2 on Tomato Root Exudates and Meloidogyne incognita Infection. Plant Dis. 2019, 103, 1551-1558. [CrossRef]

24. Hartmann, A.; Rothballer, M.; Hense, B.A.; SchrÃder, P. Bacterial quorum sensing compounds are important modulators of microbe-plant interactions. Front. Plant Sci. 2014, 5. [CrossRef]

25. Reinhold-Hurek, B.; Hurek, T. Living inside plants: Bacterial endophytes. Curr. Opin. Plant Biol. 2011, 14, 435-443. [CrossRef] [PubMed]

26. Abd El-Rahman, A.F.; Shaheen, H.A.; Abd El-Aziz, R.M.; Ibrahim, D.S.S. Influence of hydrogen cyanide-producing rhizobacteria in controlling the crown gall and root-knot nematode, Meloidogyne incognita. Egyptian J. Biol. Pest Control 2019, 29. [CrossRef]

27. Marin-Bruzos, M.; Grayston, S.J. Biological Control of Nematodes by Plant Growth Promoting Rhizobacteria: Secondary Metabolites Involved and Potential Applications. In Secondary Metabolites of Plant Growth Promoting Rhizomicroorganisms; Springer: Singapore, 2019; pp. 253-264. [CrossRef]

28. Korejo, F.; Ali, S.A.; Humayun, F.; Rahman, A.; Sultana, V.; Ara, J.; Ehteshamul-Haque, S. Management of root rotting fungi and root knot nematode with endophytic fluorescent Pseudomonas associated with Salvadora species. Pak. J. Bot. 2019, 51. [CrossRef]

29. Terefe, M.; Tefera, T.; Sakhuja, P.K. Effect of a formulation of Bacillus firmus on root-knot nematode Meloidogyne incognita infestation and the growth of tomato plants in the greenhouse and nursery. J. Invertebr. Pathol. 2009, 100, 94-99. [CrossRef] [PubMed]

30. Mehmood, U.; Inam-ul-Haq, M.; Saeed, M.; Altaf, A.; Azam, F. A Brief Review on Plant Growth Promoting Rhizobacteria (PGPR): A Key Role in Plant Growth Promotion. Plant Prot. 2018, 2, 77-82.

31. Alquéres, S.; Meneses, C.; Rouws, L.; Rothballer, M.; Baldani, I.; Schmid, M.; Hartmann, A. The Bacterial Superoxide Dismutase and Glutathione Reductase Are Crucial for Endophytic Colonization of Rice Roots by Gluconacetobacter diazotrophicus PAL5. Mol. PlantMicrobe Interact. 2013, 26, 937-945. [CrossRef] 
32. Khanna, K.; Jamwal, V.L.; Kohli, S.K.; Gandhi, S.G.; Ohri, P.; Bhardwaj, R.; Wijaya, L.; Alyemeni, M.N.; Ahmad, P. Role of plant growth promoting Bacteria (PGPRs) as biocontrol agents of Meloidogyne incognita through improved plant defense of Lycopersicon esculentum. Plant Soil 2019, 436, 325-345. [CrossRef]

33. Taylor, D.P.; Netscher, C. An improved technique for preparing perineal patterns of Meloidogyne spp. Nematologica 1974, 20, 268-269.

34. Arnon, D.I. Copper enzymes in isolated chloroplasts, polyphenoxidase in Beta vulgaris. Plant Physiol. 1949, 24, 1-15. [CrossRef]

35. Maclachlan, S.; Zalik, S. Plastid structure, chlorophyll concentration and free amino acid composition of a chlorophyll mutant of barley. Can. J. Bot. 1963, 41, 1053-1062. [CrossRef]

36. Lawrence, J. Determination of total xanthophyll and marigold oleoresin. J. Assoc. Off. Anal. Chem. 1990, 2, 970-975.

37. Wu, G.L.; Cui, J.; Tao, L.; Yang, H. Fluroxypyr triggers oxidative damage by producing superoxide and hydrogen peroxide in rice (Oryza sativa). Ecotoxicology 2009, 19, 124-132. [CrossRef] [PubMed]

38. Velikova, V.; Yordanov, I.; Edreva, A. Oxidative stress and some antioxidant systems in acid rain-treated bean plants. Plant Sci. 2000, 151, 59-66. [CrossRef]

39. Heath, R.L.; Packer, L. Photoperoxidation in isolated chloroplasts. Arch. Biochem. Biophys. 1968, 125, $189-198$. [CrossRef]

40. Kono, Y. Generation of superoxide radical during autoxidation of hydroxylamine and an assay for superoxide dismutase. Arch. Biochem. Biophys. 1978, 186, 189-195. [CrossRef]

41. Pütter, J. Peroxidases. In Methods of Enzymatic Analysis; Elsevier: Amsterdam, The Netherlands, 1974; pp. 685-690. [CrossRef]

42. Aebi, H. Catalase in vitro. In Methods Enzymology; Colowick, S., Kaplan, N., Eds.; Elsevier: Amsterdam, The Netherlands, 1984; Volume 105, pp. 121-126.

43. Flohé, L.; Günzler, W.A. Assays of glutathione peroxidase. In Methods Enzymology; Elsevier: Amsterdam, The Netherlands, 1984; pp. 114-120. [CrossRef]

44. Nakano, Y.; Asada, K. Hydrogen peroxide is scavenged by ascorbate-specific peroxidase in spinach chloroplasts. Plant Cell Physiol. 1981, 22, 867-880.

45. Dalton, D.A.; Russell, S.A.; Hanus, F.J.; Pascoe, G.A.; Evans, H.J. Enzymatic reactions of ascorbate and glutathione that prevent peroxide damage in soybean root nodules. Proc. Natl. Acad. Sci. USA 1986, 83, 3811-3815. [CrossRef]

46. Habig, W.H.; Jakoby, W.B. Assays for differentiation of glutathione S-Transferases. In Methods Enzymology; Elsevier: Amsterdam, The Netherlands, 1981; pp. 398-405. [CrossRef]

47. Carlberg, I.; Mannervik, B. Purification and characterization of the flavoenzyme glutathione reductase from rat liver. J. Biol. Chem. 1975, 250, 5475-5480.

48. Kumar, K.; Khan, P. Peroxidase and polyphenol oxidase in excised ragi (Eleusine corocana cv PR 202) leaves during senescence. Indian J. Exp. Biol. 1982, 20,412-416.

49. Noctor, G.; Foyer, C.H. Ascorbate and glutathione: Keeping active oxygen under control. Annu. Rev. Plant Biol. 1998, 49, 249-279. [CrossRef]

50. Roe, J.H.; Kuether, C.A. The determination of ascorbic acid in whole blood and urine through the 2, 4-dinitrophenylhydrazine derivavative of dehydroascorbic acid. J. Biol. Chem. 1943, 147, 399-407.

51. Martinek, R.G. Method for the determination of vitamin E (total tocopherols) in serum. Clin. Chem. 1964, 10, 1078-1086. [PubMed]

52. Singleton, V.L.; Rossi, J.A. Colorimetry of total phenolics with phosphomolybdic-phosphotungstic acid reagents. Am. J. Enol. Vitic. 1965, 16, 144-158.

53. Zhishen, J.; Mengcheng, T.; Jianming, W. The determination of flavonoid contents in mulberry and their scavenging effects on superoxide radicals. Food Chem. 1999, 64, 555-559. [CrossRef]

54. Mancinelli, A.L. Photoregulation of Anthocyanin Synthesis: VIII. Effect of Light Pretreatments. Plant Physiol. 1984, 75, 447-453. [CrossRef] [PubMed]

55. Hedge, J.; Hofreiter, B.; Whistler, R. Carbohydrate Chemistry; Academic Press: New York, NY, USA, 1962; Volume 17.

56. Miller, G.L. Use of Dinitrosalicylic Acid Reagent for Determination of Reducing Sugar. Anal. Chem. 1959, 31, 426-428. [CrossRef] 
57. Trevelyan, W.E.; Harrison, J.S. Studies on yeast metabolism. 5. The trehalose content of baker's yeast during anaerobic fermentation. Biochem. J. 1956, 62, 177-183. [CrossRef]

58. Grieve, C.M.; Grattan, S.R. Rapid assay for determination of water soluble quaternary ammonium compounds. Plant Soil 1983, 70, 303-307. [CrossRef]

59. Bates, L.S.; Waldren, R.P.; Teare, I.D. Rapid determination of free proline for water-stress studies. Plant Soil 1973, 39, 205-207. [CrossRef]

60. Lee, Y.P.; Takahashi, T. An improved colorimetric determination of amino acids with the use of ninhydrin. Anal. Biochem. 1966, 14, 71-77. [CrossRef]

61. Chen, M.-C.; Wang, M.-K.; Chiu, C.-Y.; Huang, P.-M.; King, H.-B. Determination of low molecular weight dicarboxylic acids and organic functional groups in rhizosphere and bulk soils of Tsuga and Yushania in a temperate rain forest. Plant Soil 2001, 231, 37-44. [CrossRef]

62. Gupta, R.; Singh, A.; Srivastava, M.; Shanker, K.; Pandey, R. Plant-microbe interactions endorse growth by uplifting microbial community structure of Bacopa monnieri rhizosphere under nematode stress. Microbiol. Res. 2019, 218, 87-96. [CrossRef] [PubMed]

63. Čepulyte, R.; Danquah, W.B.; Bruening, G.; Williamson, V.M. Potent Attractant for Root-Knot Nematodes in Exudates from Seedling Root Tips of Two Host Species. Sci. Rep. 2018, 8. [CrossRef] [PubMed]

64. Abd-El-Khair, H.; El-Nagdi, W.M.A.; Youssef, M.M.A.; Abd-Elgawad, M.M.M.; Dawood, M.G. Protective effect of Bacillus subtilis, B. pumilus, and Pseudomonas fluorescens isolates against root knot nematode Meloidogyne incognita on cowpea. Bull. Natl. Res. Centre 2019, 43. [CrossRef]

65. Ali, S.S.; Vidhale, N. Bacterial siderophore and their application: A review. Int. J. Curr. Microbiol. Appl. Sci. 2013, 2, 303-312.

66. Tong-Jian, X.; Fang, C.; Chao, G.; Qing-Yun, Z.; Qi-Rong, S.; Wei, R. Bacillus cereus X5 enhanced bio-organic fertilizers effectively control root-knot nematodes (Meloidogyne sp.). Pedosphere 2013, 23, 160-168.

67. Zakaria, H.M.; Kassab, A.S.; Shamseldean, M.M.; Oraby, M.M.; El-Mourshedy, M.M.F. Controlling the root-knot nematode, Meloidogyne incognita in cucumber plants using some soil bioagents and some amendments under simulated field conditions. Ann. Agric. Sci. 2013, 58, 77-82. [CrossRef]

68. Banora, M.Y.; Almaghrabi, O.A.A. Differential response of some nematode-resistant and susceptible tomato genotypes to Meloidogyne javanica infection. J. Plant Prot. Res. 2019, 59, 113-123.

69. Strajnar, P.; Širca, S.; Urek, G.; Šircelj, H.; Železnik, P.; Vodnik, D. Effect of Meloidogyne ethiopica parasitism on water management and physiological stress in tomato. Eur. J. Plant Pathol. 2012, 132, 49-57. [CrossRef]

70. Gálvez, A.; del Amor, F.M.; Ros, C.; López-Marín, J. New traits to identify physiological responses induced by different rootstocks after root-knot nematode inoculation (Meloidogyne incognita) in sweet pepper. Crop Prot. 2019, 119, 126-133. [CrossRef]

71. Nunes da Silva, M.; Pintado, M.E.; Sarmento, B.; Stamford, N.P.; Vasconcelos, M.W. A biofertilizer with diazotrophic bacteria and a filamentous fungus increases Pinus pinaster tolerance to the pinewood nematode (Bursaphelenchus xylophilus). Biol. Control 2019, 132, 72-80. [CrossRef]

72. Goulart, R.D.R.; Terra, W.C.; Salgado, S.M.D.L.; Alves, J.D.; Campos, V.P.; Fatobene, B.J.D.R.; Marchiori, P.E.R.; de Souza, S.R.; Oliveira, R.D.A.D.L. Meloidogyne paranaensis and M. exigua alter coffee physiology. Nematology 2018, 21, 459-467. [CrossRef]

73. Mazurkiewicz-Zapałowicz, K.; Wróbel, J.; Janowicz, K. Interaction Between Golden Nematode Globodera Rostochiensis (Woll.), Behrens and Soil Saprophytic Fungi-Its Influence on The Processes of Gaseous Exchange and Crop Yield of Potato (Solanum Tuberosum L.). Arch. Phytopathol. Plant Prot. 2002, 35, 279-286. [CrossRef]

74. Golinowski, W.; Grymaszewska, G. Reakcja tkanek korzenia na porażenie nicieniami z rodzaju Heterodera. Kosmos 1991, 40, 319-329.

75. Mioranza, T.M.; Inagaki, A.M.; Müller, M.A.; Stangarlin, J.R.; Guimarães, V.F.; Klein, J.; Kuhn, O.J. Gas exchange and photosynthetic light response curves in nematode-infected tomato plants treated with Thuya occidentalis. Aust. J. Crop. Sci. 2018, 12, 583-591. [CrossRef]

76. Thakur, R.K.; Dhirta, B.; Shirkot, P. Studies on Effect of Gold Nanoparticles on Meloidogyne Incognita and Tomato Plants Growth and Development; Cold Spring Harbor Laboratory: Cold Spring Harbor, NY, USA, 2018. [CrossRef]

77. Gupta, R.; Singh, A.; Ajayakumar, P.V.; Pandey, R. Microbial interference mitigates Meloidogyne incognita mediated oxidative stress and augments bacoside content in Bacopa monnieri L. Microbiol. Res. 2017, 199, 67-78. [CrossRef] [PubMed] 
78. Chavan, S.B.; Deshpande, M.V. Chitinolytic enzymes: An appraisal as a product of commercial potential. Biotechnol. Prog. 2013, 29, 833-846. [CrossRef]

79. Singh, S.P.; Gupta, R.; Gaur, R.; Srivastava, A.K. Streptomyces spp. alleviate Rhizoctonia solani mediated oxidative stress in Solanum lycopersicon. Ann. Appl. Biol. 2015, 168, 232-242. [CrossRef]

80. Singh, A.; Jain, A.; Sarma, B.K.; Upadhyay, R.S.; Singh, H.B. Rhizosphere microbes facilitate redox homeostasis in Cicer arietinum against biotic stress. Ann. Appl. Biol. 2013, 163, 33-46. [CrossRef]

81. Vos, C.; Schouteden, N.; van Tuinen, D.; Chatagnier, O.; Elsen, A.; De Waele, D.; Panis, B.; Gianinazzi-Pearson, V. Mycorrhiza-induced resistance against the root-knot nematode Meloidogyne incognita involves priming of defense gene responses in tomato. Soil Biol. Biochem. 2013, 60, 45-54. [CrossRef]

82. Bajestani, M.S.; Moghadam, E.M.; Aghnoum, R.; Rohani, H. Genotypic and Biochemical variation in the response of barley to the Root-knot nematode (Meloidogyne javanica) at seedling stage. Pakistan J. Phytopathol. 2019, 31, 07-17. [CrossRef]

83. Moghbeli, E.; Nemati, S.H.; Aroiee, H.; Olfati, J.-A. Evaluation of Resistance, Enzymatic Response, and Phenolic Compounds in Roots of F1 Cucumber Hybrids to Fusarium oxysporum F. Sp. Radicis-Cucumerinum. J. Hortic. Res. 2017, 25, 117-124. [CrossRef]

84. Sung, Y.W.; Lee, I.H.; Shim, D.; Lee, K.-L.; Nam, K.J.; Yang, J.-W.; Lee, J.J.; Kwak, S.-S.; Kim, Y.-H. Transcriptomic changes in sweetpotato peroxidases in response to infection with the root-knot nematode Meloidogyne incognita. Mol. Biol. Rep. 2019, 46, 4555-4564. [CrossRef] [PubMed]

85. Sahebani, N.; Hadavi, N. Induction of $\mathrm{H}_{2} \mathrm{O}_{2}$ and related enzymes in tomato roots infected with root knot nematode (M.javanica) by several chemical and microbial elicitors. Biocontrol Sci. Technol. 2009, 19, 301-313. [CrossRef]

86. Labudda, M. Ascorbate-glutathione pathway as an important player in redox regulation in nematode-infested plants: What we have learned so far. Physiol. Mol. Plant Pathol. 2018, 103, 47-53. [CrossRef]

87. Smirnoff, N.; Wheeler, G.L. Ascorbic Acid in Plants: Biosynthesis and Function. Crit. Rev. Plant Sci. 2000, 19, 267-290. [CrossRef]

88. Kesba, H.H.; El-Beltagi, H.S. Biochemical changes in grape rootstocks resulted from humic acid treatments in relation to nematode infection. Asian Pac. J. Trop. Biomed. 2012, 2, 287-293. [CrossRef]

89. Molinari, S.; Leonetti, P. Molecular Signaling Involved in Immune System Activation Against Root-Knot Nematodes by Bio-Control Agents in Tomato Plants; Cold Spring Harbor Laboratory: Cold Spring Harbor, NY, USA, 2019. [CrossRef]

90. Singh, U.B.; Singh, S.; Khan, W.; Malviya, D.; Sahu, P.K.; Chaurasia, R.; Sharma, S.K.; Saxena, A.K. Drechslerella dactyloides and Dactylaria brochopaga mediated induction of defense related mediator molecules in tomato plants pre-challenged with Meloidogyne incognita. Ind. Phytopathol. 2019, 72, 309-320. [CrossRef]

91. Clarke, C.R.; Vinatzer, B.A. Characterizing the Immune-Eliciting Activity of Putative Microbe-Associated Molecular Patterns in Tomato. In Methods in Molecular Biology; Springer: New York, NY, USA, 2017; pp. $249-261$. [CrossRef]

92. Galeng-Lawilao, J.; Kumar, A.; Cabasan, M.T.N.; De Waele, D. Comparison of the penetration, development and reproduction of Meloidogyne graminicola, and analysis of lignin and total phenolic content in partially resistant and resistant recombinant inbred lines of Oryza sativa. Trop. Plant Pathol. 2018, 44, 171-182. [CrossRef]

93. Chin, S. The Role of Flavonoids in the Interaction Between the Plant, Medicago truncatula and the Nematode, Meloidogyne Javanica; Australian National University: Canberra, Australia, 2019.

94. Labudda, M.; Różańska, E.; Czarnocka, W.; Sobczak, M.; Dzik, J.M. Systemic changes in photosynthesis and reactive oxygen species homeostasis in shoots of Arabidopsis thaliana infected with the beet cyst nematode Heterodera schachtii. Mol. Plant Pathol. 2018, 19, 1690-1704. [CrossRef]

95. Franceschi, V.R.; Krokene, P.; Christiansen, E.; Krekling, T. Anatomical and chemical defenses of conifer bark against bark beetles and other pests. New Phytol. 2005, 167, 353-376. [CrossRef] [PubMed]

96. Hofmann, J.; ElAshry, A.E.N.; Anwar, S.; Erban, A.; Kopka, J.; Grundler, F. Metabolic profiling reveals local and systemic responses of host plants to nematode parasitism. Plant J. 2010. [CrossRef] [PubMed]

97. Seo, Y.; Kim, Y.H. Control of Meloidogyne incognita Using Mixtures of Organic Acids. Plant Pathol. J. 2014, 30, 450-455. [CrossRef] [PubMed]

98. Radwan, M.A. Comparative suppressive effect of some organic acids against Meloidogyne incognita infecting tomato. Pakistan J. Nematol. 2017, 35, 197-208. [CrossRef] 
99. Proença, D.N.; Schwab, S.; Vidal, M.S.; Baldani,J.I.; Xavier, G.R.; Morais, P.V. The nematicide Serratia plymuthica M24T3 colonizes Arabidopsis thaliana, stimulates plant growth, and presents plant beneficial potential. Braz. J. Microbiol. 2019, 50, 777-789. [CrossRef] [PubMed]

100. Oh, M.; Han, J.W.; Lee, C.; Choi, G.J.; Kim, H. Nematicidal and Plant Growth-Promoting Activity of Enterobacter asburiae HK169: Genome Analysis Provides Insight into Its Biological Activities. J. Microbiol. Biotechnol. 2018, 28, 968-975. [CrossRef] [PubMed]

101. Shemshura, O.N.; Bekmakhanova, N.E.; Mazunina, M.N.; Meyer, S.L.F.; Rice, C.P.; Masler, E.P. Isolation and identification of nematode-antagonistic compounds from the fungus Aspergillus candidus. FEMS Microbiol. Lett. 2016, 363, fnw026. [CrossRef]

(C) 2019 by the authors. Licensee MDPI, Basel, Switzerland. This article is an open access article distributed under the terms and conditions of the Creative Commons Attribution (CC BY) license (http://creativecommons.org/licenses/by/4.0/). 